\title{
Dietary fibre and the gut-brain axis: microbiota- dependent and independent mechanisms of action
}

\author{
Danique La Torre (D), Kristin Verbeke (D) and Boushra Dalile* \\ Translational Research Center in Gastrointestinal Disorders (TARGID), Department of Chronic Diseases and Metabolism, \\ Faculty of Medicine, KU Leuven, Leuven, Belgium, and Leuven Brain Institute, KU Leuven, Leuven, Belgium \\ ${ }^{\star}$ Corresponding author. Email: boushra.dalile@kuleuven.be
}

(Received 26 April 2021; revised 19 August 2021; accepted 31 August 2021)

\begin{abstract}
Dietary fibre is an umbrella term comprising various types of carbohydrate polymers that cannot be digested nor absorbed by the human small intestine. Consumption of dietary fibre is linked to beneficial effects on cognitive and affective processes, although not all fibres produce the same effects. Fibres that increase shortchain fatty acid (SCFA) production following modulation of the gut microbiota are thought to be the most potent fibres to induce effects on cognitive and affective processes. SCFAs can exert their effects by improving central, peripheral and systemic immunity, lowering hypertension and enhancing intestinal barrier integrity. Here, we propose additional mechanisms by which dietary fibres may contribute to improvements in affective and cognitive processes. Fibre-induced modulation of the gut microbiota may influence affective processes and cognition by increasing brain-derived neurotrophic factor levels. Depending on the physicochemical properties of dietary fibre, additional effects on affect and cognition may occur via non-microbiota-related routes, such as enhancement of the immune system and lowering cholesterol levels and subsequently lowering blood pressure. Mechanistic randomised placebo-controlled trials are needed to establish the effects of dietary fibre consumption and the magnitude of explained variance in affect and cognition when incorporating measurements of microbiota-dependent and microbiota-independent mechanisms in humans.
\end{abstract}

Keywords: Dietary fibres; prebiotics; SCFA; affective processes; cognition

\section{Introduction}

Dietary fibre, which is derived from fruits and vegetables, legumes, whole-grain breads, and cereals, is an umbrella term comprising various types of carbohydrate polymers that cannot be digested nor absorbed by the human small intestine. Consequently, dietary fibre ends up in the colon, where it is fermented by the gut microbiota. Consumption of dietary fibre has been linked to various beneficial physiological effects, including effects on affective (Lawton et al., 2013) and cognitive (Sandberg et al., 2018) processes. Notably, dietary fibre consumption can aid in prevention or treatment of symptoms of depression, anxiety, and stress (Jacka et al., 2017; Silk et al., 2009), which are psychological states characterised by negative mood (e.g., worry, fear, sadness, loss of interest, or emotional tension) that are often accompanied by impaired facets of cognition. Moreover, preclinical data suggests that impaired facets of cognition, such as attention, mental flexibility, and executive functioning, can be restored by dietary fibre (Chunchai et al., 2018).

\footnotetext{
(C) The Author(s), 2021. Published by Cambridge University Press on behalf of The Nutrition Society. This is an Open Access article, distributed under the terms of the Creative Commons Attribution licence (https://creativecommons.org/licenses/by/4.0/), which permits unrestricted re-use, distribution, and reproduction in any medium, provided the original work is properly cited.
} 
Since dietary fibres vary in origin, chemical composition, and physicochemical properties (comprising solubility, fermentability, and viscosity), they can exert different effects on the body. These differences in physicochemical properties might differentially affect the communicative pathways to the brain, and consequently variably influence affective and cognitive processes. Commonly accepted mechanisms by which dietary fibres are thought to affect cognitive and affective processes are the gut microbiome and short chain fatty acids (SCFAs) (Dalile et al., 2019). Here, we shed light on additional potential mechanisms that may contribute to the positive effects of dietary fibres on these processes, such as the immune system, cholesterol, the intestinal barrier, brain-derived neurotrophic factor (BDNF), and blood pressure, and would help explain additional variance that is not explained by SCFAs. Since in human studies most evidence is associative, we also included animal studies that assess the impact of dietary fibre intake on these various mechanisms. To this end, the current review assesses microbiotadependent and microbiota-independent biological mechanisms that may underlie the effects of dietary fibre on affective processes and cognition and outlines which physicochemical properties may predict such effects.

\section{Dietary fibres: a definition}

Since dietary fibres are characteristically heterogeneous, different classifications have been used to define them, including origin, chemical composition, and physicochemical properties with additional subcategorisation based on the degree of polymerisation. The most commonly used definition of dietary fibre is according to the Codex Alimentarius, which states that dietary fibres include (1) edible carbohydrate polymers occurring in foods as consumed, (2) edible carbohydrates obtained from food raw materials by physical, enzymatic or chemical means and (3) synthetic carbohydrate polymers, which have beneficial physiological effect demonstrated by generally accepted scientific evidence (Joint FAO/WHO Food Standards Programme Secretariat of the CODEX Alimentarius Commission, 2010). In 2016, the Food and Drug Administration (FDA) defined dietary fibre as either (1) non-digestible soluble and insoluble carbohydrates (with three or more monomeric units), and lignin that are intrinsic and intact in plants, or (2) isolated or synthetic non-digestible carbohydrates (with three or more monomeric units), and induce physiological effects that are beneficial to human health (Food and Drug Administration, 2020). At that time, only seven non-digestible carbohydrates were included in the latter category ( $\beta$-glucan soluble fibre, psyllium husk, cellulose, guar gum, pectin, locust bean gum, and hydroxypropylmethylcellulose). Since then, the list has been extended with ten additional types of dietary fibre [mixed plant cell wall fibres, arabinoxylan (AX), alginate, inulin, and inulin-type fructans (ITFs), high amylose starch (resistant starch 2), galactooligosaccharides (GOS), polydextrose, resistant maltodextrin/dextrin, cross linked phosphorylated RS4, and glucomannan]. Certain types of fibres, such as ITFs and GOS fulfil the criteria of a prebiotic. Prebiotics are defined as "a substrate that is selectively utilised by host microorganisms conferring a health benefit” (Gibson et al., 2017).

\section{Properties of dietary fibres}

The physicochemical characteristics of dietary fibres are subtyped by solubility, viscosity and fermentability. Table 1 provides an overview of the most frequently investigated types of fibres and their concomitant physicochemical properties.

\section{Solubility}

Dietary fibres can be water-soluble or water-insoluble, with most plant foods containing a mixture of both. Approximately 20 per cent of consumed dietary fibre is soluble, whereas 80 per cent is insoluble. Insoluble fibres consist mainly of cellulose, hemicellulose, and lignin, and are primarily present in wheat bran, most grain products and vegetables (Cho and Dreher, 2001). Soluble fibres consist of polysaccharides such as pectin, mucilage, and gum, and are predominantly found in some fruits (e.g., dried prunes, oranges, and 


\begin{tabular}{|c|c|c|c|c|c|c|}
\hline Type of dietary fibre & Origin & Structure & Solubility & Viscosity & Fermentability & References \\
\hline Cellulose & $\begin{array}{l}\text { Cell wall of most } \\
\text { plants, fruits (e.g., } \\
\text { apples), grains and } \\
\text { vegetables (e.g., } \\
\text { green beans) }\end{array}$ & $\begin{array}{l}\text { Linear chain of } \beta(1 \rightarrow 4) \text { linked glucose } \\
\text { monomers }\end{array}$ & - & - & + & $\begin{array}{l}\text { Lattimer and } \\
\text { Haub, 2010; } \\
\text { Mudgil and } \\
\text { Barak, } 2013\end{array}$ \\
\hline \multicolumn{7}{|l|}{ ITFS } \\
\hline Inulin & $\begin{array}{l}\text { Wheat, garlic, onions, } \\
\text { chicory, artichokes } \\
\text { and bananas }\end{array}$ & $\begin{array}{l}\text { Polymer of multiple fructose monomers } \\
\text { linked by } \beta-(2 \rightarrow 1) \text { fructosyl-fructose } \\
\text { linkages }\end{array}$ & + & - & ++ & $\begin{array}{l}\text { Jenkins et al., } \\
\text { 2000; Lattimer } \\
\text { and Haub, } 2010\end{array}$ \\
\hline FOS & $\begin{array}{l}\text { Onions, garlic, } \\
\text { asparagus, wheat, } \\
\text { bananas, honey } \\
\text { and tomatoes }\end{array}$ & $\begin{array}{l}\text { Sucrose molecule (glucose - fructose } \\
\text { disaccharide, GF1) linked to one (GF2), } \\
\text { two (GF3) or three (GF4) additional } \\
\text { fructose unites, added by glycosidic } \\
\text { linkages to the fructose unit }\end{array}$ & ++ & - & ++ & $\begin{array}{l}\text { Delzenne, 2003; } \\
\text { Jenkins et al., } \\
2000\end{array}$ \\
\hline GOS & $\begin{array}{l}\text { Legumes (e.g., } \\
\text { artichokes, beans } \\
\text { and lentils) and } \\
\text { seaweed }\end{array}$ & $\begin{array}{l}\beta \text {-linked oligosaccharides made up of } \\
\text { galactose with glucose/galactose } \\
\text { present at the reducing end }\end{array}$ & + & - & ++ & $\begin{array}{l}\text { Jenkins et al., } \\
\text { 2000; Silk et al., } \\
\text { 2009; Vulevic et } \\
\text { al., } 2008\end{array}$ \\
\hline XOS & $\begin{array}{l}\text { Bamboo shoots, milk, } \\
\text { honey, fruits (e.g., } \\
\text { bananas) and } \\
\text { vegetables }\end{array}$ & Xylose units linked by $\beta-(1 \rightarrow 4)$ bonds & + & - & ++ & Qing et al., 2013 \\
\hline \multicolumn{7}{|l|}{ Hemicelluloses } \\
\hline \multirow[t]{2}{*}{$A X$} & \multirow{2}{*}{$\begin{array}{l}\text { Cell wall components } \\
\text { that constitute a } \\
\text { large part of the } \\
\text { dietary fibre } \\
\text { fraction of cereal } \\
\text { grains }\end{array}$} & \multirow{2}{*}{$\begin{array}{l}\beta-1,4 \text {-linked xylose units, substituted with } \\
\alpha \text {-L-arabinofuranosyl residues in } 0-2 \\
\text { and/or } 0-3 \text {. Some ferulic acid residues } \\
\text { may be esterified to arabinose at } 0-5\end{array}$} & $\begin{array}{l}- \text { (water } \\
\text { unextractable } \\
\text { AX) }\end{array}$ & - & - & $\begin{array}{l}\text { Courtin and } \\
\text { Delcour, } 2001\end{array}$ \\
\hline & & & $\begin{array}{l}++(\text { water } \\
\text { extractable } A X)\end{array}$ & - & + & $\begin{array}{l}\text { Courtin and } \\
\text { Delcour, } 2001\end{array}$ \\
\hline Cereal $\beta$-glucans & $\begin{array}{l}\text { Cell wall material in } \\
\text { oat, barley, rye and } \\
\text { wheat }\end{array}$ & $\begin{array}{l}\text { Linear polysaccharide of glucose polymers } \\
\text { with } \beta(1 \rightarrow 4) \text { and } \beta(1 \rightarrow 3) \text { linkages } \\
\text { between the units }\end{array}$ & ++ & ++ & ++ & $\begin{array}{l}\text { Lattimer and } \\
\text { Haub, 2010; } \\
\text { Mudgil and } \\
\text { Barak, } 2013\end{array}$ \\
\hline
\end{tabular}




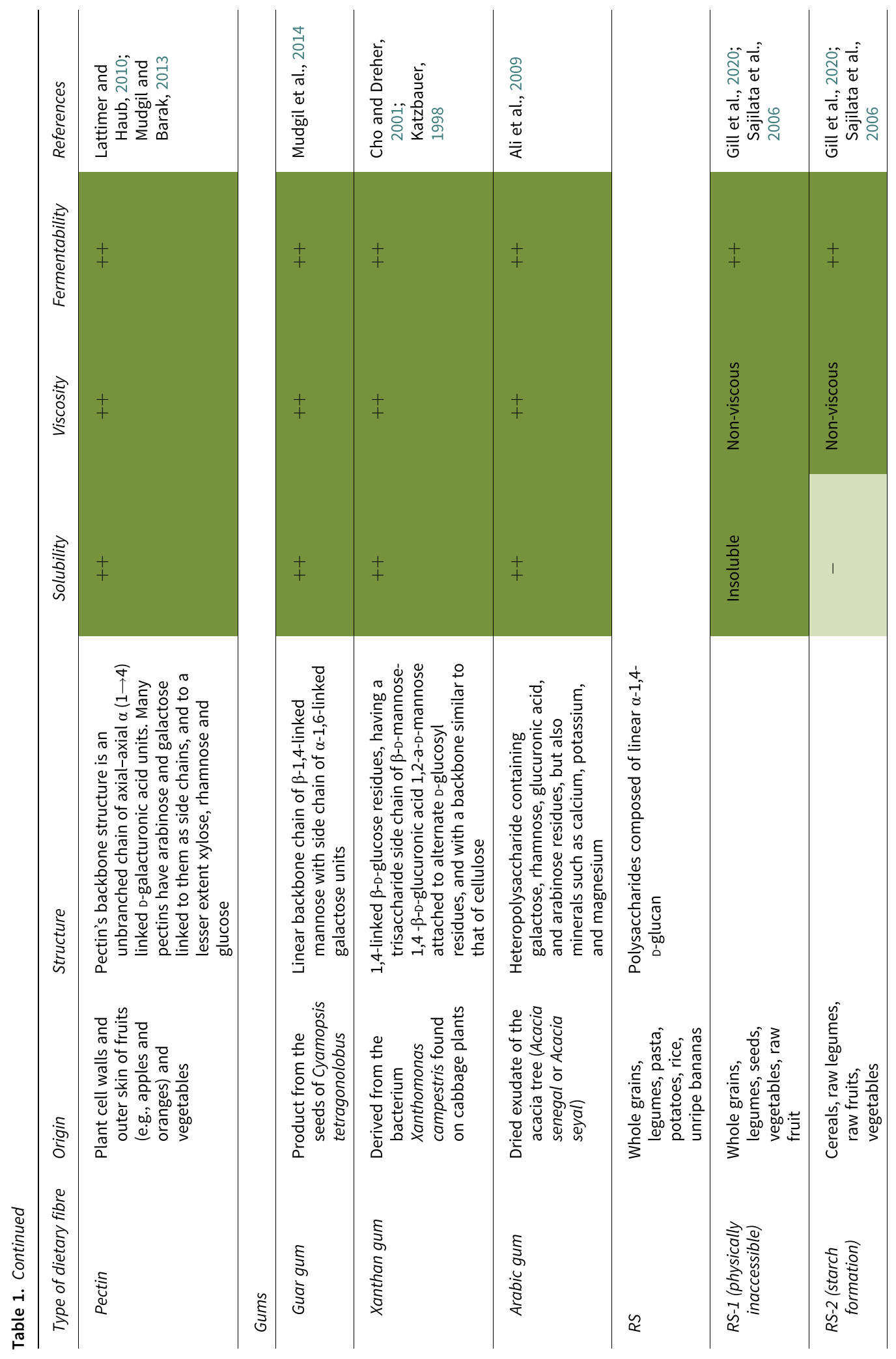


Table 1. Continued

\begin{tabular}{|c|c|c|c|c|c|}
\hline Type of dietary fibre & Structure & Solubility & Viscosity & Fermentability & References \\
\hline RS-3 (retrograded) & $\begin{array}{l}\text { Cooked and cooled } \\
\text { starch sources }\end{array}$ & - & Non-viscous/- & ++ & $\begin{array}{l}\text { Gill et al., 2020; } \\
\text { Sajilata et al., } \\
2006\end{array}$ \\
\hline $\begin{array}{l}\text { RS-4 (chemically } \\
\text { modified) }\end{array}$ & $\begin{array}{l}\text { Foods with modified } \\
\text { starches (e.g., } \\
\text { acylated starches) }\end{array}$ & $-1++$ & $-1+$ & ++ & $\begin{array}{l}\text { Gill et al., 2020; } \\
\text { Sajilata et al., } \\
2006\end{array}$ \\
\hline $\begin{array}{l}\text { RS-5 (starch-lipid } \\
\text { complex) }\end{array}$ & $\begin{array}{l}\text { Foods with modified } \\
\text { starches (e.g., } \\
\text { amylose and } \\
\text { stearic acid) }\end{array}$ & - & - & - & Gill et al., 2020 \\
\hline
\end{tabular}

Note: Degree of physicochemical properties are expressed as low (-), medium (+) or high (++).

Abbreviations: AX, arabinoxylan; FOS, fructooligosaccharides; GOS, galactooligosaccharides; ITFs, inulin-type fructans; RS, resistant starch; XOS, xylooligosaccharides. 
grapefruit), oats, barley, dried beans, and legumes (e.g., lentils and pinto beans) (Cho and Dreher, 2001). Although soluble fibres are less prevalent in foods than insoluble fibres, they have an important influence on digestive and absorptive processes, such as delaying gastric emptying, decreasing glucose absorption, enhancing immune function, and lowering total and low-density lipoprotein (LDL) cholesterol levels (Cho and Dreher, 2001; Jenkins et al., 2000). Insoluble fibres are important for shortening bowel transit time, increasing faecal bulk, and softening stool (Cho and Dreher, 2001).

\section{Viscosity}

Viscosity, the capacity to gel with water, depends on the solubility of the fibre with soluble fibres having higher viscosity. Viscous fibres reduce postprandial glucose response after carbohydrate-rich meals, lower total and LDL cholesterol levels (Jenkins et al., 2000; McRorie and McKeown, 2017), and slow gastric emptying and macronutrient absorption from the gut (McRorie and McKeown, 2017).

\section{Fermentability}

The fermentability of dietary fibre varies greatly, ranging from not at all (e.g., lignin) to almost complete fermentation (e.g., pectin) (Mudgil and Barak, 2013). Soluble fibres are fermented in the colon, whereas insoluble fibres are less and more slowly fermented. The fermentation of soluble fibres results in the production of short-chain fatty acids (SCFAs) which, in turn, exhibit anti-inflammatory effects in the gut, maintain intestinal barrier integrity (Lewis et al., 2010), induce mucin secretion in the gastrointestinal tract (Monk et al., 2017), and promote gastrointestinal motility (Cherbut et al., 1998). In addition to solubility, chain length and particle size determine fermentability with shorter polymers and small particles being more readily fermented. In in vitro incubation experiments, neutral pectin fractions produced more SCFAs and more acetate than acidic fractions, whereas rhamnose and arabinan produced high proportions of propionate (Onumpai et al., 2011). Wood derived xylan and mannan derivatives produced similar total amounts of SCFAs as fructooligosaccharides (FOS) but proportionally more propionate and butyrate, respectively (La Rosa et al., 2019). In contrast, the glycosidic bond configuration has little impact on SCFA production (Harris et al., 2017).

\section{Dietary fibre studies on cognitive and affective processes}

Here, we provide a brief overview of the state of the literature on the effects of dietary fibre on cognitive and affective processes for the sake of completeness. Cross-sectional and prospective cohort studies across the lifespan continue to show positive associations between higher dietary fibre intake and better cognitive and affective processes (Muth and Park, 2021; Swann et al., 2020). Affective processes are measured by, for instance, better mental health quality of life and lower incidents of depression and anxiety. Moreover, dietary source of fibres appears to be differentially associated with the incidence of depression (Kim et al., 2020). Despite assessing effects on the short-term, human interventional studies enable controlled administration of specific fibres and exclusion of confounding effects. These studies are displayed in Table 2. Briefly, 18 studies were found, with 7 of them (Azpiroz et al., 2017; Buigues et al., 2016; Dehhaghi et al., 2019; Farhangi et al., 2018; Grimaldi et al., 2018; Kao et al., 2019; Silk et al., 2009) conducted in populations with various mental, physical, or gastrointestinal disorders, and the remaining 11 conducted in healthy populations (Best et al., 2008, 2009, 2015; Childs et al., 2014; Lawton et al., 2013; Pasman et al., 2003; Ramnani et al., 2015; Schmidt et al., 2015; Smith, 2005; Smith et al., 2015; Talbott and Talbott, 2009). The duration of the intervention periods varied, with three studies carrying out single administration (Best et al., 2008, 2015; Smith et al., 2015), one study comprising 2 days (Pasman et al., 2003), and the others comprising 2-13 weeks (Azpiroz et al., 2017; Best et al., 2009; Buigues et al., 2016; Childs et al., 2014; Farhangi et al., 2018; Grimaldi et al., 2018; Kao et al., 2019; Kazemi et al., 2019; Lawton et al., 2013; Ramnani et al., 2015; Schmidt et al., 2015; Silk et al., 2009; Smith, 2005; Talbott and Talbott, 2009). Eleven studies utilised ITFs, with the majority of them (nine studies) showing some positive effects on affective and cognitive indices. Five studies utilised mixtures of fibre, mostly revealing positive effects 
Table 2. Human studies assessing the effect of dietary fibre interventions on mood and cognition.

\begin{tabular}{|c|c|c|c|c|c|}
\hline References & Sample & Design & Intervention & Placebo & Effect \\
\hline $\begin{array}{l}\text { Pasman et al. } \\
\text { (2003) }\end{array}$ & $\begin{array}{l}26 \text { healthy men } \\
(25-45 \text { years })\end{array}$ & $\begin{array}{l}\text { A 2-day, open, randomised, } \\
\text { crossover trial }\end{array}$ & $\begin{array}{l}\text { Simple carbohydrate breakfast } \\
\text { (high in mono and } \\
\text { disaccharides; } 2.1 \mathrm{~g} \text { fibre) } \\
\text { versus complex carbohydrate } \\
\text { breakfast (high in } \\
\text { polysaccharides; } 6.5 \mathrm{~g} \text { fibre) }\end{array}$ & None & $\begin{array}{l}\text { Complex carbohydrate breakfast } \\
\text { lowered fatigue scores relative } \\
\text { to simple carbohydrate } \\
\text { breakfast. No effects on } \\
\text { depression, anger, vigour or } \\
\text { tension scores }\end{array}$ \\
\hline Smith (2005) & $\begin{array}{l}142 \text { healthy } \\
\text { participants } \\
\text { (19-64 years) }\end{array}$ & $\begin{array}{l}\text { A 2-week, placebo-controlled, } \\
\text { crossover design with } 2 \text { weeks } \\
\text { washout period }\end{array}$ & $\begin{array}{l}2 \times 5 \mathrm{~g} / \text { day oligofructose- } \\
\text { enriched inulin }\end{array}$ & $\begin{array}{l}\text { Placebo (no further } \\
\text { details) }\end{array}$ & $\begin{array}{l}\text { Oligofructose-enriched inulin } \\
\text { decreased simple and choice } \\
\text { reaction time relative to } \\
\text { placebo. No other effects }\end{array}$ \\
\hline Best et al. (2008) & $\begin{array}{l}45 \text { healthy } \\
\text { participants } \\
\text { (40-63 years) }\end{array}$ & $\begin{array}{l}\text { An acute randomised, double- } \\
\text { blind, placebo-controlled } \\
\text { design }\end{array}$ & $\begin{array}{l}7 \text { g powdered Ambrotose } \\
\text { Complex (combination of } \\
\text { saccarides). These include } \\
\text { polysaccharides from aloe } \\
\text { vera, Larix decidua, Astragalus } \\
\text { gummifer and Anogeissus } \\
\text { latifolia, with rice starch and } \\
\text { glucosamine hydrochloride; } \\
\text { and saccharides included } \\
\text { mannose, galactose, fucose, } \\
\text { xylose, glucose, } n \text {-acetyl- } \\
\text { glucosamine, } n \text {-acetyl- } \\
\text { neuraminic acid and } n \text {-acetyl- } \\
\text { galactosamine }\end{array}$ & $\begin{array}{l}25 \mathrm{~g} \text { of glucose or } \\
\text { artificial sweetener } \\
\text { (two drops of liquid } \\
\text { Stevia) }\end{array}$ & No effects \\
\hline Best et al. (2009) & $\begin{array}{l}109 \text { healthy } \\
\text { participants }(45-60)\end{array}$ & $\begin{array}{l}\text { A } 12 \text {-week randomised, double- } \\
\text { blind, placebo-controlled }\end{array}$ & $\begin{array}{l}\text { 3.6 g/day powdered Ambrotose } \\
\text { complex (a combination of } \\
\text { plant saccharides). These } \\
\text { include polysaccharides from } \\
\text { aloe vera, Larix decidua, } \\
\text { Astragalus gummifer and } \\
\text { Anogeissus latifolia, with rice } \\
\text { starch and glucosamine } \\
\text { hydrochloride; and saccharides } \\
\text { included mannose, galactose, } \\
\text { fucose, xylose, glucose, } \\
n \text {-acetyl-glucosamine, } n \text {-acetyl- } \\
\text { neuraminic acid, and } n \text {-acetyl- } \\
\text { galactosamine }\end{array}$ & $\begin{array}{l}\text { Rice flour starch } \\
\text { powder }\end{array}$ & $\begin{array}{l}\text { Ambrotose complex improved } \\
\text { memory performance } \\
\text { (immediate recall and } \\
\text { recognition memory), well- } \\
\text { being (reduction in anger- } \\
\text { hostility and depression- } \\
\text { dejection, feeling less irritable, } \\
\text { having fewer instance of being } \\
\text { grouchy and annoyed, and } \\
\text { overall more positive and } \\
\text { happier, experience fewer } \\
\text { feelings of personal } \\
\text { inadequacy) relative to placebo }\end{array}$ \\
\hline
\end{tabular}


Table 2. Continued

\begin{tabular}{|c|c|c|c|c|c|}
\hline References & Sample & Design & Intervention & Placebo & Effect \\
\hline $\begin{array}{l}\text { Talbott and } \\
\text { Talbott (2009) }\end{array}$ & $\begin{array}{l}75 \text { marathon runners } \\
(18-53)\end{array}$ & $\begin{array}{l}\text { A 4-week randomised, double- } \\
\text { blind, placebo-controlled trial }\end{array}$ & $\begin{array}{l}250 \text { or } 500 \mathrm{mg} / \text { day of } \beta 1,3 / 1,6 \\
\text { glucan. The } \beta \text {-glucan were } \\
\text { isolated from the yeast } \\
\text { Saccharomyces cerevisiae }\end{array}$ & Rice flour & $\begin{array}{l}\text { Lower tension, fatigue, confusion, } \\
\text { and anger and higher vigour } \\
\text { scores in the treatment groups } \\
\text { relative to placebo - with some } \\
\text { exhibiting dose-depending } \\
\text { effects. A composite (global } \\
\text { mood) score revealed that } \\
\text { mood improved after both the } \\
250 \text { mg dose at 4-weeks and } \\
\text { both 2- and 4-weeks in the } \\
500 \text { mg treatment groups } \\
\text { compared to placebo }\end{array}$ \\
\hline Silk et al. (2009) & $\begin{array}{l}\text { Patients with irritable } \\
\text { bowel syndrome } \\
\text { (18-80 years) }\end{array}$ & $\begin{array}{l}\text { A } 12 \text {-week randomised, simple } \\
\text { blind (patients), placebo- } \\
\text { controlled, parallel, and } \\
\text { crossover design }\end{array}$ & $\begin{array}{l}\text { Trans-GOS mixture ( } 3,5 \text { or } 7 \mathrm{~g} / \mathrm{d}) \text {, } \\
\text { which contained: GOS, lactose, } \\
\text { glucose, and galactose }\end{array}$ & Maltodextrin & $\begin{array}{l}\text { Trans-GOS mixture decreased } \\
\text { anxiety and increased quality } \\
\text { of life scores relative to placebo }\end{array}$ \\
\hline $\begin{array}{l}\text { Lawton et al. } \\
\text { (2013) }\end{array}$ & $\begin{array}{l}153 \text { healthy low-fibre } \\
(<15 \mathrm{~g} / \text { day }) \\
\text { consumers } \\
\text { (18-50 years) }\end{array}$ & $\begin{array}{l}\text { A single centre, multi-site, open, } \\
\text { within-subjects pre-post } \\
\text { design. A 14-day non- } \\
\text { intervention (baseline, } \\
\text { habitual diet) monitoring } \\
\text { period was followed by a } \\
\text { 14-day fibre consumption } \\
\text { (intervention) period }\end{array}$ & $\begin{array}{l}\text { Cereals ( } 5.4 \mathrm{~g} \text { of fibres with } 3.5 \mathrm{~g} \text { of } \\
\text { wheat bran). The source of } \\
\text { fibres was from bran shreds, } \\
\text { wheat bran flakes, wheat bran } \\
\text { flakes with sultanas, frosted } \\
\text { mini wheats, raisin mini } \\
\text { wheats, chocolate wheat bran } \\
\text { flakes, apple and fig wheat } \\
\text { bran flakes }\end{array}$ & $\begin{array}{l}\text { No comparator (non- } \\
\text { intervention, } \\
\text { baseline } \\
\text { monitoring period) }\end{array}$ & $\begin{array}{l}\text { Breakfast cereals increased } \\
\text { subjective perception of } \\
\text { general well-being (feeling less } \\
\text { fat, more mentally alert, slim, } \\
\text { happy, and energetic whilst } \\
\text { experiencing less stress, mental } \\
\text { and physical tiredness, } \\
\text { difficulty concentrating, and } \\
\text { fewer headaches) }\end{array}$ \\
\hline $\begin{array}{l}\text { Childs et al. } \\
\text { (2014) }\end{array}$ & $\begin{array}{l}44 \text { healthy } \\
\text { participants } \\
\text { (25-65 years) }\end{array}$ & $\begin{array}{l}\text { A 3-week randomised, double- } \\
\text { blind, placebo-controlled, } \\
\text { crossover design with 2-week } \\
\text { washout period }\end{array}$ & $\begin{array}{l}\text { Prebiotic: } 8 \mathrm{~g} / \text { day XOS; Probiotic: } \\
\text { Bifidobacterium } \\
\text { animalis subsp. lactis (Bi-07; } \\
109 \text { colony-forming units } \\
\text { (CFU)/d); or, Synbiotic: } \\
\text { combined }\end{array}$ & Maltodextrin & $\begin{array}{l}\text { XOS increased participant- } \\
\text { reported vitality and } \\
\text { happiness relative to placebo }\end{array}$ \\
\hline $\begin{array}{l}\text { Smith et al. } \\
\text { (2015) }\end{array}$ & $\begin{array}{l}47 \text { healthy } \\
\text { participants (19-30) }\end{array}$ & $\begin{array}{l}\text { An acute randomised, double- } \\
\text { blind, placebo-controlled } \\
\text { crossover design }\end{array}$ & $5 \mathrm{~g} /$ day Inulin & Maltodextrin & $\begin{array}{l}\text { Inulin resulted in higher } \\
\text { happiness scores, and } \\
\text { improved memory [greater } \\
\text { accuracy on a recognition } \\
\text { memory task, albeit with }\end{array}$ \\
\hline
\end{tabular}


Table 2. Continued

\begin{tabular}{|c|c|c|c|c|c|}
\hline References & Sample & Design & Intervention & Placebo & Effect \\
\hline & & & & & $\begin{array}{l}\text { slower reaction time, and } \\
\text { improved recall performance } \\
\text { (immediate and delayed)] } \\
\text { relative to placebo }\end{array}$ \\
\hline $\begin{array}{l}\text { Schmidt et al } \\
\text { (2015) }\end{array}$ & $\begin{array}{l}45 \text { healthy volunteers } \\
\text { (18-45 years) }\end{array}$ & $\begin{array}{l}\text { 3-week, double-blind, } \\
\text { randomised, placebo- } \\
\text { controlled trial }\end{array}$ & $\begin{array}{l}5.5 \text { g/day FOS or Bimuno }{ }^{\circledR}-G O S \\
\quad\left(\text { B-GOS }^{\circledR}\right)\end{array}$ & Maltodextrin & $\begin{array}{l}\text { B-GOS }{ }^{\circledR} \text { lowered attentional } \\
\text { vigilance to negative versus } \\
\text { positive stimuli on dot-probe } \\
\text { task as well as lowered cortisol } \\
\text { awakening response (CAR) }{ }^{\mathrm{a}} \\
\text { relative to placebo. No effects } \\
\text { of FOS }\end{array}$ \\
\hline $\begin{array}{l}\text { Ramnani et al. } \\
\text { (2015) }\end{array}$ & $\begin{array}{l}38 \text { healthy } \\
\text { participants } \\
\text { (18-50 years, } \\
\text { mean age } 38)\end{array}$ & $\begin{array}{l}\text { A 3-week randomised, double- } \\
\text { blind, placebo-controlled, } \\
\text { crossover design with 2-week } \\
\text { washout period }\end{array}$ & $\begin{array}{l}\text { Agave fructan ( } 5 \mathrm{~g} / \text { day; a purified } \\
\text { powder extracted from Agave } \\
\text { tequilana Weber var. Azul.) }\end{array}$ & Maltodextrin & No effects \\
\hline Best et al. (2015) & $\begin{array}{l}73 \text { healthy } \\
\text { participants } \\
\text { (45-60 years) }\end{array}$ & $\begin{array}{l}\text { An acute randomised, double- } \\
\text { blind, placebo-controlled trial }\end{array}$ & $\begin{array}{l}4 \mathrm{~g} \text { of a proprietary mixture of } \\
\text { non-starch polysaccharides } \\
\text { (NSPs; Ambrotose }{ }^{\circledR} \text { complex). } \\
\text { This included arabinogalactan, } \\
\text { aloe vera gel extract, gum } \\
\text { ghatti, gum tragacanth that } \\
\text { contain gluco- and } \\
\text { galactomannans, acetylated } \\
\text { mannans, acemannan, } \\
\text { glucosamine } \mathrm{HCL} \text {, and rice } \\
\text { starch }\end{array}$ & $\begin{array}{l}\text { Rice flour or sucrose } \\
\text { control }\end{array}$ & $\begin{array}{l}\text { Non-starch polysaccharides } \\
\text { resulted in glucose- } \\
\text { independent improvements in } \\
\text { recognition memory and } \\
\text { working memory relative to } \\
\text { rice flour and sucrose control }\end{array}$ \\
\hline $\begin{array}{l}\text { Buigues et al. } \\
\qquad(2016)\end{array}$ & $\begin{array}{l}\text { Participants with } \\
\text { frailty syndrome } \\
\text { (66-90 years) }\end{array}$ & $\begin{array}{l}\text { A } 13 \text {-week randomised, double- } \\
\text { blind, placebo-controlled trial }\end{array}$ & $\begin{array}{l}7.5 \mathrm{~g} / \text { day Inulin plus FOS } \\
\text { (Darmocare Pre) }\end{array}$ & Maltodextrin & $\begin{array}{l}\text { Inulin + FOS reduced fatigue } \\
\text { relative to placebo }\end{array}$ \\
\hline $\begin{array}{l}\text { Azpiroz et al. } \\
\text { (2017) }\end{array}$ & $\begin{array}{l}79 \text { irritable bowel } \\
\text { syndrome patients } \\
\text { with rectal } \\
\text { hypersensitivity } \\
\text { (18-60 years old) }\end{array}$ & $\begin{array}{l}\text { 4-week, double-blind, } \\
\text { randomised, placebo- } \\
\text { controlled trial }\end{array}$ & $5 \mathrm{~g} /$ day short chain FOS (scFOS) & Maltodextrin & $\begin{array}{l}\text { scFOS lowered anxiety scores } \\
\text { relative to placebo }\end{array}$ \\
\hline
\end{tabular}


Table 2. Continued

\begin{tabular}{|c|c|c|c|c|c|}
\hline References & Sample & Design & Intervention & Placebo & Effect \\
\hline $\begin{array}{l}\text { Farhangi et al. } \\
\text { (2018) }\end{array}$ & $\begin{array}{l}55 \text { females with type } 2 \\
\text { diabetes mellitus }\end{array}$ & $\begin{array}{l}\text { 8-week, double-blind, } \\
\text { randomised, placebo- } \\
\text { controlled trial }\end{array}$ & $\begin{array}{l}10 \text { g/day Nutriose }{ }^{\circledR} 06 \text { (a resistant } \\
\text { dextrin), which contains } \\
\text { glucose polymer derived from } \\
\text { maize, wheat, or other edible } \\
\text { starch }\end{array}$ & Maltodextrin & $\begin{array}{l}\text { Resistant dextrin lowered cortisol } \\
\text { levels, depression, anxiety, and } \\
\text { stress scale scores, and } \\
\text { improved scores on general } \\
\text { health questionnaire relative to } \\
\text { placebo }\end{array}$ \\
\hline $\begin{array}{l}\text { Grimaldi et al. } \\
(2018)\end{array}$ & $\begin{array}{l}26 \text { children } \\
\text { (4-11 years) with } \\
\text { autism spectrum } \\
\text { disorders }\end{array}$ & $\begin{array}{l}\text { 6-week randomised, double- } \\
\text { blind, placebo-controlled trial }\end{array}$ & $\begin{array}{l}\text { B-GOS }{ }^{\circledR} \text { mixture (Bimuno; } 1.8 \mathrm{~g} \text { : } \\
80 \% \text { GOS content) }\end{array}$ & Maltodextrin & $\begin{array}{l}\text { B-GOS }{ }^{\circledR} \text { improved social } \\
\text { behaviour scores (i.e., scores } \\
\text { were lower) relative to placebo }\end{array}$ \\
\hline \multirow[t]{2}{*}{$\begin{array}{l}\text { Kazemi et al. } \\
\qquad(2019)\end{array}$} & \multirow[t]{2}{*}{$\begin{array}{l}110 \text { participants with } \\
\text { major depressive } \\
\text { disorder } \\
\text { (18-50 years) }\end{array}$} & \multirow[t]{2}{*}{$\begin{array}{l}\text { 8-week randomised, double- } \\
\text { blind, placebo-controlled trial }\end{array}$} & $\begin{array}{l}\text { L. helveticus R0052 and } B \text {. longum } \\
\text { R0175 (CNCM strain I- } 3470 \text { ) } \\
\text { bacteria at a dosage of } \\
10 \text { billion colony-forming units } \\
\text { ( } \geq 10 \times 10^{9} \text { CFU) per } 5 \mathrm{~g} \text { sachet/ } \\
\text { day }\end{array}$ & \multirow[t]{2}{*}{$\begin{array}{l}\text { Excipients used were } \\
\text { as follows: xylitol, } \\
\text { maltodextrin, plum } \\
\text { flavour and malic } \\
\text { acid }\end{array}$} & \multirow[t]{2}{*}{$\begin{array}{l}\text { Probiotic supplementation } \\
\text { resulted in a significant } \\
\text { decrease in depression score } \\
\text { compared to the placebo and } \\
\text { prebiotic supplementation }\end{array}$} \\
\hline & & & $\begin{array}{l}\text { Prebiotic product was composed } \\
\text { of GOS and } 0.2 \% \text { Plum flavour }\end{array}$ & & \\
\hline Kao et al. (2019) & $\begin{array}{l}39 \text { non-hospitalised } \\
\text { participants } \\
\text { (18-60 years) with } \\
\text { psychosis, stable on } \\
\text { antipsychotic } \\
\text { medication for at } \\
\text { least } 3 \text { months prior } \\
\text { to recruitment, with } \\
\text { global cognitive } \\
\text { score } 0.5 \text { SD below } \\
\text { the healthy average }\end{array}$ & $\begin{array}{l}\text { A 12-week randomised, double- } \\
\text { blind, placebo-controlled } \\
\text { crossover trial, without } \\
\text { washout period }\end{array}$ & $5.5 \mathrm{~g} /$ day B-GOS $^{\circledast}$ & Maltodextrin & $\begin{array}{l}\text { B-GOS }{ }^{\circledR} \text { increased the cognitive } \\
\text { assessment's composite score } \\
\text { (reflecting verbal memory, } \\
\text { working memory, motor speed, } \\
\text { verbal fluency, attention, speed } \\
\text { of information processing, and } \\
\text { executive functions) relative to } \\
\text { placebo. Placebo improved } \\
\text { verbal fluency alone. There was } \\
\text { a significant pre- versus post- } \\
\text { effect of B-GOS }{ }^{\circledast} \text { on the } \\
\text { executive, but not verbal, } \\
\text { domains }\end{array}$ \\
\hline
\end{tabular}

Abbreviations: GOS, galactooligosaccharides; FOS, fructooligosaccharides; XOS, xylooligosaccharides.

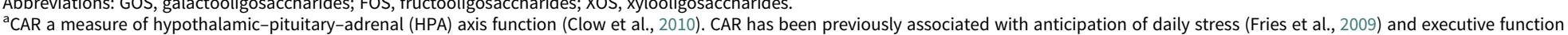
(Butler et al., 2017). 


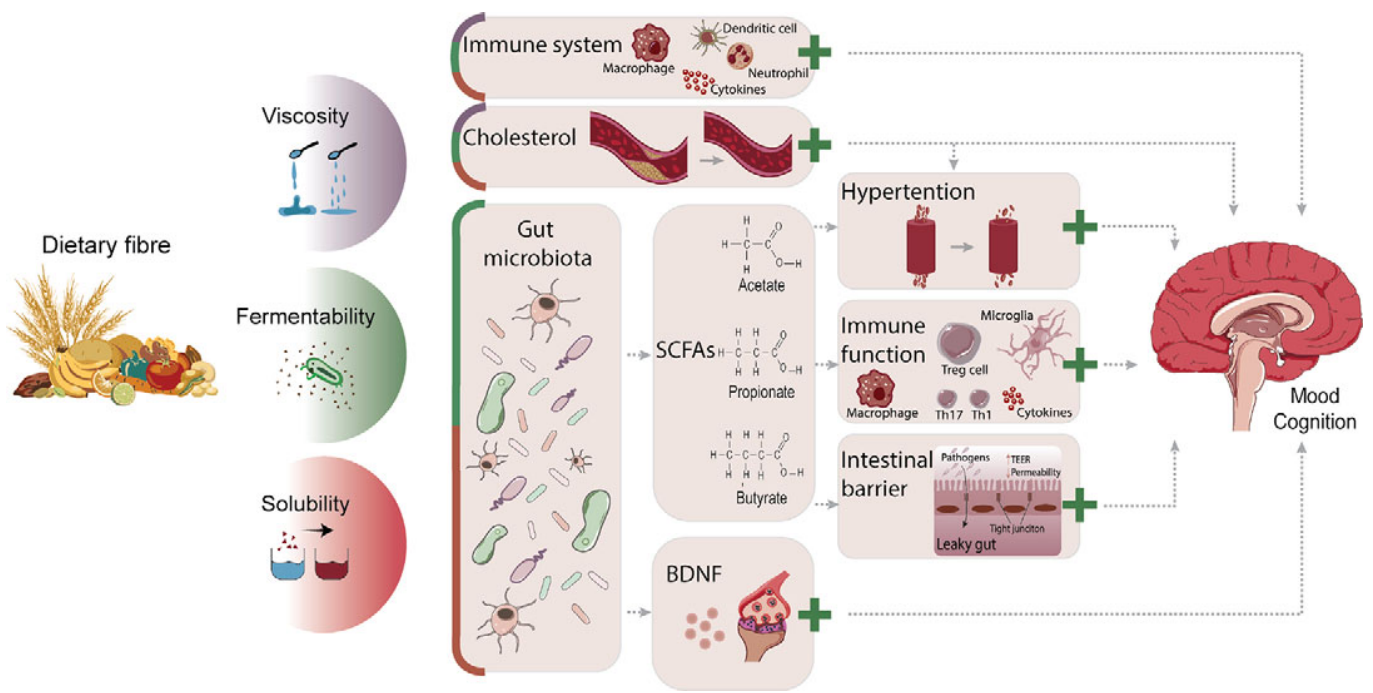

Figure 1. Overview of potential biological mechanisms underlying dietary fibres' effects on mood and cognition according to physicochemical properties. The degree of viscosity, fermentability, and solubility of dietary fibres influences gut microbiota composition and function, the immune system, as well as cholesterol levels, through which mood and cognition can be modulated. Via the direct immune route, viscous, fermentable, and soluble fibres can reduce pro-inflammatory cytokines, lower numbers and activation of splenic macrophages and DCs, and increase neutrophils in the blood. Cholesterol levels can be lowered by viscous, fermentable, and soluble fibres and impact the brain, but can also indirectly affect it by reducing hypertension. Fermentability and solubility of dietary fibre modulate the gut microbiota, by which it can influence affective and cognitive processes via SCFA-dependent mechanisms or BDNF levels. SCFAs can lower hypertension as well as improve immune function and intestinal barrier integrity. Via the indirect immune route, SCFAs suppress pro-inflammatory reactions by reducing pro-inflammatory cytokines, increasing antiinflammatory cytokines and $\mathrm{T}_{\text {reg }}$ cells, as well as restoring microglial cell morphology and reversing microglial immaturity. All these mechanisms have been associated with modulation of mood and cognition in health and disease. The likelihood that the different biological mechanisms underlie dietary fibres' effect on mood and cognition are displayed in proportion, with larger cubicle areas reflecting increased potential. The green plus sign indicates beneficial effects. BDNF, brain-derived neurotrophic factor; DCs, dendritic cells; $\mathrm{T}_{\text {reg }}$ cells, regulatory T-cells; SCFAs, short chain fatty acids.

of interventions, unless it was administered only once. One study administrated $\beta$-glucans and one study administered resistant starch. Not all studies are of equal quality, with some lacking proper control conditions. Notably, most human intervention studies administered dietary fibre supplements rather than whole foods. Whole foods are not only rich in dietary fibre but also contain minerals and antioxidants that may improve mood and cognition (Gomez-Pinilla, 2008). Moreover, it cannot be excluded that some placebos (e.g., maltodextrin) may have had an effect on mood and/or cognition as well, possibly via gut-independent mechanisms (Kendig et al., 2014). Future intervention studies should take such effects into account. Some fibres such as pectin, hemicelluloses (e.g., AX), and gums (e.g., guar, xanthan, and Arabic gum) are yet to be explored in the context of mood and cognition. As these fibres are highly viscous, they may affect mood and cognition through microbiota-independent mechanisms as discussed below. Overall, the majority of studies point to beneficial effects on mood and cognition, but none of these studies causally addresses potential mechanisms of action. In the next section, we will discuss potential mechanisms, both microbiota-dependent as well as microbiota-independent, that may be involved in dietary fibre's beneficial effects on affective and cognitive processes.

\section{Biological mechanisms}

Dietary fibre may affect mood and cognition via various biological mechanisms, both microbiotadependent and microbiota-independent, which are reviewed in this section. Figure 1 provides an 
overview of the different biological mechanisms that may underlie dietary fibres' effect on affective and cognitive processes according to their physicochemical properties.

\section{Gut microbiome}

Dietary fibre's ability to influence affective and cognitive processes is most likely through its interactions with the gut microbiome. The gut microbiome refers to the $1 \times 10^{13}$ to $1 \times 10^{14}$ microorganisms that reside in the human large intestine, which is one of the most densely and diversely colonised organs in the human body. Pre-clinical studies suggest that the gut microbiome plays an important modulating role in affective and cognitive processes. Studies in germ-free (GF) mice suggested a causal role of the gut microbiota in developing brain function and behaviour, as those mice exhibit compromised social, cognitive, and anxiety-like behaviours (Desbonnet et al., 2014), such as reduced non-spatial memory, lower social motivation, and symptoms of anxiety compared to their conventionally raised specific pathogen-free (SPF) counterparts (Clarke et al., 2013; Desbonnet et al., 2014). Also, faecal microbiota transplantation of "depressive microbiota" derived from patients with major depressive disorder (MDD; a disorder specifically known for its symptoms of negative mood and impaired cognition) to GF mice (Zheng et al., 2016) resulted in depression-like behaviours relative to colonisation with "healthy microbiota" derived from healthy donors.

Human studies also suggest that differences in the gut microbiome composition are associated with mood and cognition. For instance, gut microbiota composition of healthy subjects differs from that of patients suffering from MDD. Specifically, the relative abundance of Firmicutes (Jiang et al., 2015), Bifidobacteria and Lactobacilli (Aizawa et al., 2016) appears lower in MDD patients compared to healthy controls, whereas Actinobacteria, Proteobacteria, and Bacteroidetes appear to be higher (Jiang et al., 2015). Increases in the relative abundance of Bifidobacteria and Lactobacilli in particular have been associated with lower anxiety and better memory and learning in both rodents (Bravo et al., 2011) and humans (Messaoudi et al., 2011). Nevertheless, it seems unlikely that bacterial strains are directly responsible for these effects. Rather, it is speculated that bacterial metabolites like SCFAs and BDNF mediate the interaction between the microbiota and psychological functioning.

\section{Short-chain fatty acids}

Soluble fibres (e.g., pectin and gums) provide substrates for bacterial fermentation, which in turn leads to the production of SCFAs in the colon. Acetate, propionate, and butyrate are the most abundant SCFAs, and they are present in the colon in an approximate molar ratio of 60:20:20, respectively. Type and availability of substrate, as well as gut transit time and composition of the gut microbiota influence the levels and relative proportions of SCFAs in the colon. Following their production by microbial fermentation of dietary fibre, SCFAs are rapidly absorbed by colonic cells via monocarboxylate transporters and produce energy for the cells. Those that are not absorbed travel via the basolateral membrane into the portal circulation. In the liver, SCFAs are incorporated in glucose, cholesterol, and fatty acids, thus only small amounts actually reach systemic circulation, and subsequently the brain (Boets et al., 2017).

SCFAs and cognitive and affective processes While numerous animal studies have relied on intracerebroventricular (ICV), intraperitoneal, subcutaneous, and oral administrations to deliver SCFAs and investigate their impact on brain and behaviour (see Dalile et al., 2019), few studies explored whether the effects of dietary fibre/prebiotics on affective and cognitive functioning are mediated by or correlated with the observed increases in SCFA levels. One of these studies showed that FOS- and GOS-induced increases in cecal SCFAs correlated with effects on depressive and anxious behaviour and stress responses in mice (Burokas et al., 2017). Moreover, drinking water supplemented with a GOS mixture (B-GOS; 3 per cent) for 3 weeks increased plasma acetate levels and upregulated subunits of the $N$-methyl-D-aspartate receptor (NMDAR) in the brain (Gronier et al., 2018; Kao et al., 2018), which is implicated in synaptic plasticity and memory formation, as well as Acetyl Co-A Carboxylase mRNA, an enzyme in the brain 
that plays an important role in supplying fatty acids for myelination. Indeed, in one of these studies, mice fed with the GOS mixture gained greater cognitive flexibility (Gronier et al., 2018). Unfortunately, the other did not test whether the GOS mixture induced changes in cognition (Kao et al., 2018). Direct administration of acetate also induced similar neurochemical changes as that of GOS (Gronier et al., 2018), suggesting that acetate may play a mechanistic role in the observed effects of GOS administration.

Unfortunately, studies in humans administering prebiotics and assessing effects on affective and cognitive processes do not quantify SCFAs and do not explore the extent to which circulating SCFAs mediate the observed effects (Dalile et al., 2019). However, one study found that increasing colonic propionate by consumption of $10 \mathrm{~g}$ of an inulin-propionate ester (thereby delivering of $2.36 \mathrm{~g}$ propionate to the colon, which is 2.5 times habitual daily propionate production) influenced brain anticipatory reward responses during a functional magnetic resonance imaging (fMRI) food picture evaluation task in non-obese men (Byrne et al., 2016). In parallel, the subjective appeal of high-energy food pictures decreased and energy intake during an ad libitum meal was reduced. These results support the mediating role of SCFAs in microbiota-gut-brain axis communication. Moreover, our group recently showed that daily administration of known amounts of a SCFA mixture equivalent to 20 or $10 \mathrm{~g}$ of AX (174.2 mmol acetate, $13.3 \mathrm{mmol}$ propionate, and $52.4 \mathrm{mmol}$ butyrate, or half the dose, respectively) to the colon of healthy men for 1 week significantly reduced the cortisol response to an acute psychosocial stress challenge (Dalile et al., 2020). Furthermore, we found that the increase in circulating SCFAs was associated with a decrease in cortisol response to stress. This preliminary study indicates that SCFAs are clearly an important mechanism through which fermentable fibres can affect HPA axis (a major neuroendocrine system that regulates stress responses as well as affective processes) reactivity to stress.

Conceptually, SCFAs may influence affective and cognitive processes by influencing multiple pathways that have been reviewed elsewhere (Dalile et al., 2019). However, the extent to which increasing the substrate of SCFAs (soluble fibres) increases SCFA concentrations and consequently influences affective and cognitive processes, remains understudied. In the following sections, we focus on potential mechanisms by which fibre consumption may alter affective and cognitive processes via interactions with SCFAs and other microbiota-gut-brain axis mediators, namely, the immune system, the intestinal barrier, and hypertension. As studies that directly investigate the effect of dietary fibre on SCFAs and these mediators and subsequent changes in affective and cognitive processes are currently lacking, we summarise the available evidence for an effect of SCFAs on these intermediate systems and for the involvement of these systems in the regulation of affective and cognitive processes.

\section{Immune system (indirect effects)}

Immune system and cognitive and affective processes The immune system is important for both affective and cognitive processes. Challenging the immune system activates cytokines which are involved in the repair of damaged tissue and the restoration of homeostasis. The inflammatory response may also elicit deleterious effects, such as alterations in mood and cognition. This became evident from, for instance, a study vaccinating healthy volunteers with Salmonella typhi which increased IL-6, IL-1Ra, and tumour necrosis factor (TNF)- $\alpha$, but also decreased mood without any signs of physical sickness (Wright et al., 2005). Other studies using acute inflammatory stimulation showed similar results (Brydon et al., 2009; Strike et al., 2004). Also, endotoxin-induced inflammation showed a dose-dependent elevation in pro-inflammatory cytokines IL-6 and TNF- $\alpha$, but also anti-inflammatory cytokine IL-10 (Grigoleit et al., 2011). These elevations were accompanied by a dose-dependent increase in anxiety, negative mood, and poor long-term memory. Involvement of inflammation in negative mood and poor cognitive function is supported by numerous reviews that repeatedly showed an increased incidence of negative mood symptoms with elevated levels of pro-inflammatory markers (CRP, TNF- $\alpha$, IL-1 $\beta$, IL-2, and IL6) in peripheral blood and cerebrospinal fluid (CSF) in patients with MDD (Dowlati et al., 2010; Hannestad et al., 2011; Hiles et al., 2012). Regarding cognition, higher levels of CRP are associated with impairment in several cognitive domains such as with lower psychomotor speed and poorer executive function (Krogh et al., 2014). 
Reducing inflammation has been shown to improve mood (Allison and Ditor, 2015). Moreover, mood stabilisers such as lithium and valproate suppressed IL-6 levels in patients with bipolar disorder compared to untreated patients (Kim et al., 2007). Atypical antipsychotics, which are used as a treatment for both MDD and bipolar disorder, have also been shown to decrease levels of TNF- $\alpha$ and IL- 6 in animal models (Bian et al., 2008; Kato et al., 2007). Furthermore, meta-analyses assessing various cytokine levels after antidepressant treatment in people with depression show significant decreases in IL-6, IL-1 $\beta$, and CRP (Hannestad et al., 2011; Hiles et al., 2012). It seems therefore likely that inflammation plays a significant role in mood. To this end, reducing inflammation may aid negative mood symptoms in some individuals.

SCFAs and immune system SCFAs are able to modulate the immune system. SCFAs may reduce inflammation by modulating molecular signalling pathways, including free fatty acid receptor (FFAR) 2 and 3 activation (Vinolo et al., 2011), and histone deacetylation (HDAC) inhibition (Waldecker et al., 2008). As SCFAs directly interact with FFAR2 on immune cells, which is suggested to regulate regulatory T-cells ( $\mathrm{T}_{\text {reg }}$ cells) in the colon (Smith et al., 2013), $\mathrm{T}_{\text {reg }}$ cells may then suppress immune responses, thereby reducing inflammation.

Of all SCFAs, butyrate seems the most potent SCFA in modulating the immune system. Butyrate increases the expression of anti-inflammatory molecules in dendritic cells (DCs) and macrophages, thereby supporting $\mathrm{T}_{\text {reg }}$ differentiation (Singh et al., 2014), and hence suppress inflammation. Furthermore, due to its ability to inhibit HDAC activity, butyrate decreases the secretion of proinflammatory cytokines interleukin (IL)-12 and IL-6 in dendritic cells and allows dendritic cells to promote antiinflammatory cytokine IL-10-secreting T cells (Chang et al., 2014). Moreover, butyrate inhibits the production of pro-inflammatory cytokines interferon (IFN)-y and IL-2 (Looijer-Van Langen and Dieleman, 2009). Propionate may also modulate inflammation by inducing forkhead box P3 (FOXP3) expression, a protein that regulates the development and function of $\mathrm{T}_{\text {regs }}$ (Arpaia et al., 2013). Furthermore, both propionate and acetate have been found to increase the production of antiinflammatory cytokine IL-10 (Cavaglieri et al., 2003).

Indeed, most animal studies using prebiotics indicate beneficial effects on the immune system by lowering proinflammatory cytokine expression. For instance, gene expression of pro-inflammatory cytokines IL- $1 \beta$ and (TNF)- $\alpha$ decreased in the brain of mice fed with a high fibre ( 5 per cent inulin) diet but not in mice fed a low fibre (1 per cent cellulose) diet (Matt et al., 2018). The decrease in IL- $\beta$ and TNF- $\alpha$ correlated significantly with faecal butyrate levels, with higher butyrate levels corresponding with lower pro-inflammatory gene expression. Furthermore, 3-week administration of a FOS + GOS mixture (dissolved in drinking water for $0.3-0.4 \mathrm{~g} /$ mouse/day) reduced the elevations in proinflammatory cytokine levels (IL-6 and TNF- $\alpha$ ) caused by chronic stress induction in C57BL/6J male mice (Burokas et al., 2017). Moreover, mice fed with a high fermentable fibre (10 per cent pectin) diet became less sick and recovered faster from lipopolysaccharide (LPS)-induced sickness compared to mice fed with non-fermentable fibre (5 per cent cellulose) (Sherry et al., 2010). LPS-stimulated macrophages from the mice fed with pectin showed decreased pro-inflammatory cytokines IL-1 $\beta$, TNF- $\alpha$, interferon (IFN)- $\gamma$, IL-12, and nitrate, and increased anti-inflammatory cytokine IL-1RA compared to mice fed with cellulose. With regards to brainbased inflammation levels, increased levels of anti-inflammatory IL-1RA and IL-4 mRNA, and a decrease in pro-inflammatory IL- $1 \beta$ and TNF- $\alpha$ were observed in mice fed with pectin compared to mice fed with cellulose (Sherry et al., 2010). Since IL-4 expression is stimulated by histone acetylation, the authors hypothesised that the increased butyrate concentrations observed as a result from dietary fibre fermentation of pectin stimulated IL-4, and hence may aid immune response regulation (McLoughlin et al., 2017).

In humans, few studies have administered SCFAs and found an effect on inflammation as shown by a systematic review where only two of five studies revealed statistically significant decreases in serum inflammatory markers, namely, decreases in IL-1 $\beta$ following colonic infusion of SCFA mixture, and decreases in TNF levels following rectal acetate administration. Some studies using prebiotics support the hypothesis that SCFAs induce immunomodulatory effects SCFAs. For instance, in healthy elderly, consumption of a mixture of GOS (B-GOS; $5.5 \mathrm{~g}$ /day) for 10 weeks increased levels of anti-inflammatory cytokine IL-10, and lowered levels of pro-inflammatory cytokines IL-1, IL-6, and TNF- $\alpha$ (Vulevic et al., 
2008). Furthermore, supplementation with inulin and xylooligosaccharides (XOS; $6.64 \mathrm{~g} /$ day) for 4 weeks lowered the expression of pro-inflammatory IL-1b, IL-8, IL-12, and TNF- $\alpha$, whereas it increased anti-inflammatory IL-10 and IL-13 in the blood of healthy subjects (Lecerf et al., 2012). In a recent metaanalysis, 9 out of 13 studies reported a significant decrease in one or more systemic pro-inflammatory cytokine (primarily TNF- $\alpha$, IL-6, c-reactive protein (CRP), or IFN- $\gamma$ ) after consumption of prebiotic oligosaccharides compared with control (McLoughlin et al., 2017). In contrast, in two studies that were conducted in healthy participants, CRP, TNF- $\alpha$, and IL- 6 increased following oligosaccharide supplementation. Another systematic review, conducted in 10 prebiotic and synbiotic (supplements combining probiotics and prebiotics) trials, of which 7 prebiotic and 3 synbiotic, representing 534 obese/overweight subjects, also found inconsistent effects of prebiotic treatment on immunomodulation. They found that only 6 out of 10 trials (two with GOS, one with inulin, and three with different synbiotics) reduced CRP levels, four out of four trials (one with oligofructose-enriched inulin, one with inulin, and two with different synbiotics) reduced levels of IL-6 and/or TNF, and four out of the five trials (one with oligofructose-enriched inulin, one with inulin, one with GOS, and one with different synbiotics) lowered endotoxin levels (Fernandes et al., 2017). Taken together, it might still be too early to promote the use of prebiotics for reduction of low-grade inflammation. However, the evidence seems promising and more studies are needed to conclude whether prebiotics can lower inflammation via increased SCFA production in humans, and in turn promote beneficial effects on mood and cognition.

\section{Intestinal barrier}

Intestinal barrier and cognitive and affective processes The intestinal barrier is mainly responsible for regulating the absorption of nutrients, electrolytes, and water from the lumen, and to prevent pathogenic microorganisms and toxic luminal substances to enter the host. A dysfunctional intestinal barrier may lead to increased intestinal permeability, and hence to the translocation of luminal antigens, bacteria, and toxins through the intestinal wall into the blood stream. In turn, this may cause low-grade inflammation (Caspani and Swann, 2019) and hence may affect affective and cognitive processes. Indeed, some studies report associations between depressive symptoms and increased levels of indirect markers of intestinal permeability such as intestinal-type fatty acid-binding protein (I-FABP), fatty acid-binding protein 2 (FABP2), LPS, and zonulin (Ohlsson et al., 2019; Stevens et al., 2018). Moreover, a study using a direct measure of intestinal permeability (lactulose to mannitol ratio) also found a positive association with depression severity (Calarge et al., 2019).

SCFAs and intestinal barrier SCFAs are the preferred energy substrates for the colonic epithelium (Cushing et al., 2015) and can contribute to enhanced intestinal barrier function. This has been shown in in vitro and in in vivo experiments in which the application of individual and combinations of SCFAs increased transepithelial electrical resistance (Feng et al., 2018; Suzuki et al., 2008), decreased paracellular transport markers (Suzuki et al., 2008), and stimulated the formation of tight-junctions (Feng et al., 2018). Furthermore, SCFAs may protect the intestinal barrier from disruption induced by LPS through the inhibition of the NLPR3 inflammasome and autophagy (Feng et al., 2018).

Interestingly, an experimental study showed that 1-week oral administration of a SCFA mixture (67.5 $\mathrm{mM}$ acetate, $25 \mathrm{mM}$ propionate, and $40 \mathrm{mM}$ butyrate) alleviated stress-induced increases in intestinal permeability and decreased depressive-like behaviour in mice (Van De Wouw et al., 2018). Moreover, animal studies show that inulin supplementation ( 0.5 per cent as well as 1 per cent) increased expression of intestinal barrier function-related genes after Salmonella enterica infection in SPF chickens (Song et al., 2020). In obese mice, oligofructose increased the relative abundance of Bifidobacterium spp., leading to increases in GLP-2 and tight-junctions, lower levels of inflammation, and a significant improvement of intestinal permeability (Cani et al., 2009). As ITFs stimulate SCFA production, the effect is likely mediated by SCFAs, although this is speculative as SCFA concentrations were not measured. 
Human studies that evaluated the impact of dietary fibre on intestinal permeability yielded inconsistent results. Administration of green bananas and pectin for 1 week significantly reduced intestinal permeability and stool output in children with diarrhoea (Rabbani et al., 2001). Another study in healthy subjects found a significant reduction in intestinal permeability markers zonulin and GLP-2 after consumption of inulin-pasta (8 weeks) compared to control pasta (Russo et al., 2012). In contrast, a high dose of inulin (30-35 g/day) for 1 week in patients on liquid enteral nutrition did not affect intestinal permeability (Sobotka et al., 1997) neither did supplementation with GOS (5.5 g/day) for 12 weeks in men with well-controlled type 2 diabetes (Pedersen et al., 2016).

These results suggest that the beneficial effects of SCFA on intestinal permeability are not always evident from human studies. Fermentable fibres may induce beneficial effects on affective and cognitive processes via stimulating SCFA production. However, there is a need for human studies that assess whether improvements in intestinal barrier function by means of SCFA stimulation are also associated with improvements in mood and cognition, albeit by attenuating stress-induced negative effects, to confirm this speculation.

\section{Hypertension}

Hypertension and cognitive and affective processes Hypertension, also known as high blood pressure, is a well-established risk factor for cognitive impairment and dementia (Forte et al., 2020). Cognitive impairment is more frequent in patients with hypertension, and this is positively associated with the severity (stage) of hypertension (Muela et al., 2017). Moreover, the prevalence of anxiety disorders is higher in patients with essential hypertension (Vetere et al., 2007). However, it remains to be established to what extent a reduction in blood pressure improves affective processes and cognition. A systematic review and meta-analysis of randomised controlled trials (RCTs) indicated that pharmacological treatment of hypertension reduces cognitive decline in older adults (Gupta et al., 2020). On the other hand, recent large-scale associative studies report mixed findings. In 14,195 hypertensive older adults from the United States and Australia, the use of beta blockers alone or combined with angiotensinreceptor blockers was associated with depressive symptoms, but this was not the case when using angiotensin-receptor blockers on its own, angiotensin-converting enzyme inhibitors, calcium channel blockers, or any other possible combination of drugs among them (Agustini et al., 2020). However, another cross-sectional study comprising 1.8 million patients from Scotland reported that angiotensin antagonists and calcium channel blockers were associated with episodes of MDD in hypertensive patients with or without history of mood disorders (Shaw et al., 2020). Another nation-wide population-based study of 5.4 million people in Denmark found that no drugs belonging to angiotensin agents, calcium antagonists, $\beta$-blockers, or diuretics were associated with an increased risk of depression. In contrast, angiotensin agents, calcium antagonists, and $\beta$-blockers were associated with decreased rates of depression. Moreover, non-clinical evidence indicates that mood and blood pressure are related, with increasing intensity of negative moods (stress, anxiety, and anger) being associated with increased blood pressure, with feeling tired (low energy) being associated with the opposite pattern, while changes in intensity in positive mood (happy) showing little changes in blood pressure (Shapiro et al., 2001).

SCFAs and hypertension Meta-analyses and reviews of RCTs reveal that higher dietary fibre consumption reduces blood pressure, an effect that is most pronounced in patients with hypertension, regardless of the type of fibre (Aleixandre and Miguel, 2016). Some studies report differences in gut microbiota composition, particularly in SCFA-producers, as well as in SCFA profiles in spontaneously hypertensive rats (SHR) and in hypertensive patients (Yang et al., 2015). For example, patients with high blood pressure exhibit significantly less butyrate-producers such as Roseburia and Eubacterium but also lower plasma butyrate concentrations compared to normotensive subjects (Kim et al., 2018). Furthermore, intraperitoneal or intramedullary butyrate administration (Kim et al., 2018; Wang et al., 2017), acetate (Marcques et al., 2017), and propionate (Bartolomaeus et al., 2019) administration in drinking water resulted in anti-hypertensive effects in rodents. Most recently, expression levels of butyratesensing receptors FFAR3 and olfactory receptor (OLFR) 59 in the hypothalamus of SHR were found to be 
lower than in control rats, likely underlying the reduced effects of centrally administered butyrate on blood pressure in the SHR. Finally, functional magnetic resonance imaging revealed reduced activation of cardio regulatory brain regions of SHR compared to controls following ICV injection of butyrate to reach physiological concentrations $(3-5 \mu \mathrm{M} / \mathrm{L}$ ) in the CSF (Yang et al., 2019). Only correlational evidence exists in humans, which indicate that higher SCFA-producing bacteria are associated with lower blood pressure and high faecal SCFA levels (De La Cuesta-Zuluaga et al., 2019; Verhaar et al., 2020). Studies that aim to reduce hypertension in humans by supplementing prebiotics or other dietary fibres would benefit from quantifying SCFAs to determine the extent to which they mediate the effect of these dietary interventions on blood pressure. These studies suggest that more research is needed to understand the role of hypertension in mood and cognition, and non-pharmacological interventions such as dietary fibre or SCFA supplementation may be ripe targets for such research.

\section{Brain-derived neurotrophic factor}

BDNF is a nerve growth factor found in the brain and in the periphery with an important function in normal neural development and in long-term memory. It is considered as a potential marker for neuronal integrity and brain functions. As central and peripheral BDNF are highly correlated in rats $(r=0.86)$ (Harris et al., 2016), circulating levels of BDNF may be used as an appropriate measure for brain levels of BDNF. Dietary fibre may indirectly increase circulating BDNF levels via modification of the microbiota, in particular levels of Bifidobacterium and Lactobacillus. Increases in the relative abundance of these strains and consequent increases in BDNF levels were accompanied by a reduction in depressive symptoms as well as improvements in cognitive performance in both animal (Bercik et al., 2010, 2011) and human studies (Haghighat et al., 2019).

Dietary fibres have indeed shown to increase BDNF levels in both animals and humans, and some already found associations with improvements in cognition. For instance, in a rat study administering placebo, inulin, E. faecium, or E. faecium + inulin, BDNF levels only increased in the probiotic and synbiotic group, but not in the prebiotic group, with only the synbiotic group showing improved memory (Romo-Araiza et al., 2018). Furthermore, in healthy subjects, an evening meal consisting of rye kernel bread increased plasma BDNF levels by 27 per cent at fasting on the next morning compared to white wheat bread (Sandberg et al., 2018). Consumption of the same bread for three consecutive days was associated with a higher abundance of Prevotella compared to the white wheat bread (Prykhodko et al., 2018), and the Prevotella genus was positively associated with plasma levels of BDNF. Unfortunately, no plasma SCFAs were measured which prevented evaluating the relationship between SCFAs and BDNF. Despite evidence that butyrate increases acetylation around the promoters of BDNF, thereby increasing its transcription (Intlekofer et al., 2013) and the myriad pre-clinical studies showing that it increases following butyrate administration (Stilling et al., 2016), our recent study in healthy subjects showed that colonic administration of SCFAs did not alter serum BDNF levels (Dalile et al., 2020). Together, the evidence thus far seems to indicate that the relationship between dietary fibre consumption and BDNF levels is mediated by changes in gut microbiota composition, rather than increases in colonic or circulating SCFAs.

\section{Direct effects of dietary fibre on the immune system}

\section{Dietary fibre and immune system}

Few studies explored immune effects of dietary fibres that are independent of the gut microbiota. A recent study demonstrated that dietary cellulose supplementation modulates the immune response. Mice were fed either a normal diet or a high-fibre cellulose diet for 2 weeks and were, subsequently, injected with endotoxin (LPS). Mice fed the high-fibre cellulose diet showed lower levels of proinflammatory cytokines (IL-1 $\alpha$, IL-1 $\beta$, and IFN- $\alpha$ ), lower numbers and activation of splenic macrophages and DCs, and hyporesponsiveness of T cells (Di Caro et al., 2019). Splenic macrophages and DCs are innate effector cells that are crucial for the host defence to protect against bacterial infections (Di Caro et al., 2019). Since cellulose is hardly fermentable, the observed effects likely arose from a direct interaction of the fibre with the immune system, rather than from SCFA production. 
Also, other glucans, more specifically $\beta$-1,3/1,6-glucans, modulate the innate and acquired immune system. Those compounds bind to pattern recognition receptors including complement receptor 3 , scavenger receptors, lactosylceramide, and dectin-1, which are expressed on cells of myeloid origin, including macrophages, dendritic cells, and neutrophils (Murphy et al., 2010). Although small amounts of $\beta$-glucan may be absorbed after oral administration, it is most likely that $\beta$-glucan primarily act in the gut epithelium. $\beta$-Glucan has been shown useful in the prevention of treatment of allergic disease. No studies to date have evaluated whether the impact of $\beta$-glucan on the immune system results in improvements in cognitive or affective processes.

\section{Cholesterol}

\section{Cholesterol and cognitive and affective processes}

Cholesterol is important for normal brain function and our mental well-being as well as cognition. However, its involvement is complex. Cholesterol demand by neurons in the brain is very high, since it is implicated in a variety of neuronal processes such as neurite formation and synaptic activity. Several studies found that higher levels of LDL cholesterol were associated with depressive mood in men (Kim et al., 2019; Tedders et al., 2011) whereas low levels of high-density lipoprotein (HDL) cholesterol were significantly associated with depression symptoms in women (Tedders et al., 2011) and men (Lehto et al., 2010), and is a potential risk factor for developing a mood disorder in females (Kim et al., 2018). Up to 44 per cent of the subjects who were diagnosed with a mood disorder suffered from mild hypercholesterolemia (>5.2 and $6.2 \mathrm{mmol} / \mathrm{L}$ ) and 21 per cent from hypercholesterolemia $(>6.2 \mathrm{mmol} / \mathrm{L}$ ) (Davison and Kaplan, 2012). Importantly, dietary cholesterol cannot cross the blood brain barrier. Therefore, the mechanisms by which cholesterol influences learning and memory are thought to combine peripheral (atherogenic and proinflammatory) and central (accumulation of intracellular beta amyloid) effects.

There is some evidence that pharmacological reduction of plasma cholesterol with statins, the most common cholesterol-lowering drugs, may improve cognitive function in subjects without dementia (Schreurs, 2010). However, the effects of statins on mood modulation remain controversial. For instance, chronic statin treatment in rats $(10 \mathrm{mg} / \mathrm{kg}$ atorvastatin; $10 \mathrm{mg} / \mathrm{kg}$ simvastatin; $30 \mathrm{mg} / \mathrm{kg}$ pravastatin) reduced anxious behaviour in the open-field task (Citraro et al., 2014; Wang and Gao, 2009). Preclinical studies using the forced swimming test also support the anti-depressant effects of statin treatment (Can et al., 2012). Another study demonstrated that statin treatment decreased the risk of depression (Yang et al., 2003). In contrast, low dose statin treatment (simvastatin $1 \mathrm{mg} / \mathrm{kg}$; atorvastatin $0.5 \mathrm{mg} / \mathrm{kg}$ ) did not improve spatial memory and learning in guinea pigs, but instead increased levels of anxiety (Maggo et al., 2012). Furthermore, some studies in humans found that depressive symptoms increased rather than attenuated after statin treatment (Lechleitner et al., 1992; Morales et al., 2006). It is possible that lowering cholesterol induces positive effects on cognitive and affective processes by lowering blood pressure (see section "Hypertension").

\section{Dietary fibre and cholesterol}

Soluble rather than insoluble fibres possess cholesterol lowering abilities in humans. The mechanism is most likely related to the viscous properties of soluble fibre. By increasing the viscosity in the small intestine, reabsorption of bile acids is reduced, in turn leading to increased de novo synthesis of bile acids from cholesterol in the liver and lower circulating cholesterol levels (Fuller et al., 2016). The role of $\beta$ glucan in lowering cholesterol has been extensively documented and led the U.S. Food and Drug Administration (FDA) to authorise the use of health claims on oat-containing products, stating that consumption of $\beta$-glucans at least 3 g per day lowers the risk of cardiovascular disease (Food and Drug Administration, 2019). These health claims have also been approved by the European Commission, as well as in various other jurisdictions (European Commision, 2011, 2012). A meta-analysis showed that also pectin, soluble fibre from psyllium, and guar gum have cholesterol-lowering abilities (Brown et al., 1999). Viscous fibres should be utilised in intervention studies to test their effects of affective and 
cognitive processes, and if supported, investigate whether their cholesterol-lowering ability drives the effects on brain function in humans.

\section{Conclusion}

Collectively, studies suggest that dietary fibres may be promising in inducing psychological changes in cognitive and affective processes. The evidence base indicates that fermentable fibres, such as ITFs, $\beta$-glucans, pectin, and gums, are the strongest candidates to modulate these psychological functions. This is mainly due to their ability to modulate the microbiota and increase SCFA production. However, their ability to increase BDNF levels may also reinforce their effects on cognitive and affective processes. On the other hand, viscous fibres such as $\beta$-glucan and non-fermentable fibres such as cellulose may exert beneficial effects on cognitive and affective processes via microbiota-independent mechanisms such as lowering cholesterol and inflammation, respectively. Notably, a research gap remains, where the effects of different types of fibres on mood and cognition via the proposed mechanisms still needs to be investigated. In addition, while preclinical studies of dietary fibres on gastrointestinal mechanisms are ample, welldesigned studies of dietary fibre effects on mood and cognition with simultaneous assessment of putative mechanisms of actions in humans are needed. The aim with this review was to outline potential additional microbiota-dependent and independent mechanism through which different fibre properties can act to affect affective and cognitive processes in order to give a more complete picture of the effects of dietary fibres and to help explain additional variance in inter-individual psychological responses to fibre consumption. The resolution of various mechanistic and functional links outlined here may better facilitate personalised nutrition for maintaining optimal psychological functioning in states of health or disease.

Acknowledgement. The authors would like to thank Francesca Zoppas for her helpful contribution to content of the review.

Data availability statement. Data sharing is not applicable to this article as no new data were created or analysed.

Notes on contributors. Danique La Torre is a PhD student in the Translational Research Center in Gastrointestinal Disorders (TARGID) at KU Leuven. Her research focuses on the interaction between stress and intestinal permeability, and dietary and physical interventions that could modulate this interaction.

Kristin Verbeke is a Pharmacist by training, and now a Full Professor and head of the Translational Research Center in Gastrointestinal Disorders (TARGID) at KU Leuven. She has published widely on the bacterial colonic metabolism in humans, including on the development of analytical methods to quantify bacterial metabolism as well as dietary intervention studies that aim to modulate the gut microbiome.

Boushra Dalile is a Junior Postdoctoral researcher at the Translational Research Center in Gastrointestinal Disorders (TARGID), KU Leuven. She conducts research within the gut-brain axis, mainly revolving around the role of the bacterial metabolites short-chain fatty acids in human stress sensitivity and anxiety.

Funding. The PhD of B.D. is financially supported by an unrestricted grant from Société des Produits Nestlé S.A.

Disclosure. The authors declare none.

Author contributions. Conceptualization, D.L.T., K.V., B.D.; Supervision, K.V., B.D.; Visualisation, B.D., D.L.T.; Writing original draft, D.L.T., K.V., B.D.; Writing - review and editing, D.L.T., K.V., B.D. All authors have read an approved the final version of this manuscript.

\section{References}

Agustini B, Mohebbi M, Woods RL, McNeil JJ, Nelson MR, Shah RC, Murray AM, Ernst ME, Reid CM, Tonkin A, Lockery JE and Berk M (2020) The association of antihypertensive use and depressive symptoms in a large older population with hypertension living in Australia and the United States: A cross-sectional study. Journal of Human Hypertension 34(11), 787-794. https://doi.org/10.1038/s41371-020-0303-y

Aizawa E, Tsuji H, Asahara T, Takahashi T, Teraishi T, Yoshida S, Ota M, Koga N, Hattori K and Kunugi H (2016) Possible association of Bifidobacterium and Lactobacillus in the gut microbiota of patients with major depressive disorder. Journal of Affective Disorders 202, 254-257. https://doi.org/10.1016/j.jad.2016.05.038

Aleixandre A and Miguel M (2016) Dietary fiber and blood pressure control. Food \& Function 7, 1864. https://doi.org/10.1039/ c5fo00950b 
Ali BH, Ziada A and Blunden G (2009) Biological effects of gum arabic: A review of some recent research. Food and Chemical Toxicology 47, 1-8. https://doi.org/10.1016/j.fct.2008.07.001

Allison DJ and Ditor DS (2015) Targeting inflammation to influence mood following spinal cord injury: A randomized clinical trial. Journal of Neuroinflammation 12, 204. https://doi.org/10.1186/s12974-015-0425-2

Arpaia N, Campbell C, Fan X, Dikiy S, Van Der Veeken J, Deroos P, Liu H, Cross JR, Pfeffer K, Coffer PJ and Rudensky AY (2013) Metabolites produced by commensal bacteria promote peripheral regulatory T-cell generation. Nature 504(7480), 451-455. https://doi.org/10.1038/nature12726

Azpiroz F, Dubray C, Bernalier-Donadille A, Cardot J-M, Accarino A, Serra J, Wagner A, Respondek F and Dapoigny M (2017) Effects of scFOS on the composition of fecal microbiota and anxiety in patients with irritable bowel syndrome: A randomized, double blind, placebo controlled study. Neurogastroenterology \& Motility 29(2), e12911. https:/doi.org/ 10.1111/nmo.12911

Bartolomaeus H, Balogh A, Yakoub M, Homann S, Markó L, Höges S, Tsvetkov D, Krannich A, Wundersitz S, Avery EG, Haase N, Kräker K, Hering L, Maase M, Kusche-Vihrog K, Grandoch M, Fielitz J, Kempa S, Gollasch M, Zhumadilov Z, Kozhakhmetov S, Kushugulova A, Eckardt KU, Dechend R, Rump LC, Forslund SK, Müller DN, Stegbauer J and Wilck N (2019) Short-chain fatty acid propionate protects from hypertensive cardiovascular damage. Circulation 139(11), 1407-1421. https://doi.org/10.1161/CIRCULATIONAHA.118.036652

Bercik P, Park AJ, Sinclair D, Khoshdel A, Lu J, Huang X, Deng Y, Blennerhassett PA, Fahnestock M, Moine D, Berger B, Huizinga JD, Kunze W, Mclean PG, Bergonzelli GE, Collins SM and Verdu EF (2011) The anxiolytic effect of Bifidobacterium longum NCC3001 involves vagal pathways for gut-brain communication. Neurogastroenterology \& Motility 23, 1132-e544. https://doi.org/10.1111/j.1365-2982.2011.01796.x

Bercik P, Verdu EF, Foster JA, Macri J, Potter M, Huang X, Malinowski P, Jackson W, Blennerhassett P, Neufeld KA, Lu J, Khan WI, Corthesy-Theulaz I, Cherbut C, Bergonzelli GE and Collins SM (2010) Chronic gastrointestinal inflammation induces anxiety-like behavior and alters central nervous system biochemistry in mice. Gastroenterology 139, $2102-2112$. https://doi.org/10.1053/j.gastro.2010.06.063

Best T, Bryan J and Burns N (2008) An investigation of the effects of saccharides on the memory performance of middle-aged adults. Journal of Nutrition, Health and Aging 12(9), 657-662. https://doi.org/10.1007/bf03008278

Best T, Howe P, Bryan J, Buckley J and Scholey A (2015) Acute effects of a dietary non-starch polysaccharide supplement on cognitive performance in healthy middle-aged adults acute effects of a dietary non-starch polysaccharide supplement on cognitive performance in healthy middle-aged adults. Nutritional Neuroscience 18(2), 76-86. https://doi.org/10.1179/ 1476830513Y.0000000101

Best T, Kemps E and Bryan J (2009) Saccharide effects on cognition and well-being in middle-aged adults: A randomized controlled trial. Developmental Neuropsychology 35(1), 66-80. https://doi.org/10.1080/87565640903325709.

Bian Q, Kato T, Monji A, Hashioka S, Mizoguchi Y, Horikawa H and Kanba S (2008) The effect of atypical antipsychotics, perospirone, ziprasidone and quetiapine on microglial activation induced by interferon- $\gamma$. Progress in Neuro-Psychopharmacology \& Biological Psychiatry 32, 42-48. https://doi.org/10.1016/j.pnpbp.2007.06.031

Boets E, Gomand SV, Deroover L, Preston T, Vermeulen K, De Preter V, Hamer HM, Van Den Mooter G, De Vuyst L, Courtin CM, Annaert P, Delcour JA and Verbeke KA (2017) Systemic availability and metabolism of colonic-derived short-chain fatty acids in healthy subjects: A stable isotope study. The Journal of Physiology 2, 541-555. https://doi.org/ 10.1113/JP272613

Bravo JA, Forsythe P, Chew MV, Escaravage E, Savignac HM, Dinan TG, Bienenstock J, Cryan JF and Designed JFC (2011) Ingestion of lactobacillus strain regulates emotional behavior and central GABA receptor expression in a mouse via the vagus nerve. PNAS 108(38), 16050-16055. https://doi.org/10.1073/pnas.1102999108

Brown L, Rosner B, Willett WW and Sacks FM (1999) Cholesterol-lowering effects of dietary fiber: A meta-analysis. American Journal of Clinical Nutrition 69, 30-42. https://doi.org/10.1093/ajcn/69.1.30.

Brydon L, Walker C, Wawrzyniak A, Whitehead D, Okamura H, Yajima J, Tsuda A and Steptoe A (2009) Synergistic effects of psychological and immune stressors on inflammatory cytokine and sickness responses in humans. Brain, Behavior, and Immunity 23(2), 217-224. https://doi.org/10.1016/j.bbi.2008.09.007

Buigues C, Fernández-Garrido J, Pruimboom L, Hoogland AJ, Navarro-Martínez R, Martínez-Martínez M, Verdejo Y, Carmen Mascarós M, Peris C and Cauli O (2016) Effect of a prebiotic formulation on frailty syndrome: A randomized, double-blind clinical trial. International Journal of Molecular Sciences 17(6), 932. https://doi.org/10.3390/ijms17060932

Burokas A, Arboleya S, Moloney RD, Peterson VL, Murphy K, Clarke G, Stanton C, Dinan TG and Cryan JF (2017) Targeting the microbiota-gut-brain axis: Prebiotics have anxiolytic and antidepressant-like effects and reverse the impact of chronic stress in mice. Biological Psychiatry 82(1), 472-487. https://doi.org/10.1016/j.biopsych.2016.12.031

Butler K, Klaus K, Edwards L and Pennington K (2017) Elevated cortisol awakening response associated with early life stress and impaired executive function in healthy adult males. Hormones and Behavior 95, 13-21. https://doi.org/10.1016/ j.yhbeh.2017.07.013

Byrne CS, Chambers ES, Alhabeeb H, Chhina N, Morrison DJ, Preston T, Tedford C, Fitzpatrick J, Irani C, Busza A, Garcia-Perez I, Fountana S, Holmes E, Goldstone AP and Frost GS (2016) Increased colonic propionate reduces 
anticipatory reward responses in the human striatum to high-energy foods. The American Journal of Clinical Nutrition 104, 5-14. https://doi.org/10.3945/ajcn.115.126706

Calarge CA, Devaraj S and Shulman RJ (2019) Gut permeability and depressive symptom severity in unmedicated adolescents. Journal of Affective Disorders 246, 586-594. https://doi.org/10.1016/j.jad.2018.12.077

Can ÖD, Ulupınar E, Özkay ÜD, Yegin B and Öztürk Y (2012) The effect of simvastatin treatment on behavioral parameters, cognitive performance, and hippocampal morphology in rats fed a standard or a high-fat diet. Behavioural Pharmacology 23, 582-592. https://doi.org/10.1097/FBP.0b013e328356c3f2

Cani PD, Possemiers S, Van De Wiele T, Guiot Y, Everard A, Rottier O, Geurts L, Naslain D, Neyrinck A, Lambert DM, Muccioli GG and Delzenne NM (2009) Changes in gut microbiota control inflammation in obese mice through a mechanism involving GLP-2-driven improvement of gut permeability. Gut 58(8), 1091-1103. https://doi.org/10.1136/ gut.2008.165886

Caspani G and Swann J (2019) Small talk: Microbial metabolites involved in the signaling from microbiota to brain. Current Opinion in Pharmacology 48, 99-106. https://doi.org/10.1016/j.coph.2019.08.001

Cavaglieri CR, Nishiyama A, Claudio Fernandes L, Curi R, Miles EA and Calder PC (2003) Differential effects of short-chain fatty acids on proliferation and production of pro-and anti-inflammatory cytokines by cultured lymphocytes. Life Sciences 73, 1683-1690. https://doi.org/10.1016/S0024-3205(03)00490-9

Chang PV, Hao L, Offermanns S and Medzhitov R (2014) The microbial metabolite butyrate regulates intestinal macrophage function via histone deacetylase inhibition. PNAS 111(6), 2247-2252. https://doi.org/10.1073/pnas.1322269111

Cherbut C, Ferrier L, Rozé C, Anini Y, Blottière H, Lecannu G and Galmiche J-P (1998) Short-chain fatty acids modify colonic motility through nerves and polypeptide YY release in the rat. American Journal of Physiology 275, G1415-G1422.

Childs CE, Röytiö H, Alhoniemi E, Fekete AA, Forssten SD, Hudjec N, Lim YN, Steger CJ, Yaqoob P, Tuohy KM, Rastall RA, Ouwehand AC and Gibson GR (2014) Xylo-oligosaccharides alone or in synbiotic combination with Bifidobacterium animalis subsp. lactis induce bifidogenesis and modulate markers of immune function in healthy adults: A double-blind, placebo-controlled, randomised, factorial cross-over study. British Journal of Nutrition 111, 1945-1956. https://doi.org/ $10.1017 /$ S0007114513004261

Cho SS and Dreher ML (2001) Handbook of Dietary Fiber. New York: Taylor \& Francis.

Chunchai T, Thunapong W, Yasom S, Wanchai K, Eaimworawuthikul S, Metzler G, Lungkaphin A, Pongchaidecha A, Sirilun S, Chaiyasut C, Pratchayasakul W, Thiennimitr P, Chattipakorn N and Chattipakorn SC (2018) Decreased microglial activation through gut-brain axis by prebiotics, probiotics, or synbiotics effectively restored cognitive function in obese-insulin resistant rats. Journal of Neuroinflammation 15, 11. https://doi.org/10.1186/s12974-018-1055-2

Citraro R, Chimirri S, Aiello R, Gallelli L, Trimboli F, Britti D, De Sarro G and Russo E (2014) Protective effects of some statins on epileptogenesis and depressive-like behavior in WAG/Rij rats, a genetic animal model of absence epilepsy. Epilepsia 55(8), 1284-1291. https://doi.org/10.1111/epi.12686

Clarke G, Grenham S, Scully P, Fitzgerald P, Moloney RD, Shanahan F, Dinan TG and Cryan JF (2013) The microbiomegut-brain axis during early life regulates the hippocampal serotonergic system in a sex-dependent manner. Molecular Psychiatry 18(6), 666-673. https://doi.org/10.1038/mp.2012.77

Clow A, Hucklebridge F, Stalder T, Evans P and Thorn L (2010) The cortisol awakening response: More than a measure of HPA axis function. Neuroscience and Biobehavioral Reviews 35, 97-103. https://doi.org/10.1016/j.neubiorev.2009.12.011

Courtin CM and Delcour JA (2001) Relative activity of endoxylanases towards water-extractable and water-unextractable arabinoxylan. Journal of Cereal Science 33, 301-312. https://doi.org/10.1006/jcrs.2000.0354

Cushing K, Alvarado DM and Ciorba MA (2015) Butyrate and mucosal inflammation: New scientific evidence supports clinical observation. Clinical and Translational Gastroenterology 6, 108. https://doi.org/10.1038/ctg.2015.34

Dalile B, Van Oudenhove L, Vervliet B and Verbeke K (2019) The role of short-chain fatty acids in microbiota-gut-brain communication. Nature Reviews Gastroenterology and Hepatology 16(8), 461-478. https://doi.org/10.1038/s41575-0190157-3

Dalile B, Vervliet B, Bergonzelli G, Verbeke K and Van Oudenhove L (2020) Colon-delivered short-chain fatty acids attenuate the cortisol response to psychosocial stress in healthy men: A randomized, placebo-controlled trial. Neuropsychopharmacology 45(13), 2257-2266. https://doi.org/10.1038/s41386-020-0732-x

Davison KM and Kaplan BJ (2012) Food intake and blood cholesterol levels of community-based adults with mood disorders. BMC Psychiatry 12, 10. https://doi.org/10.1186/1471-244X-12-10

De La Cuesta-Zuluaga, J., Mueller, N. T., Álvarez-Quintero, R., Velásquez-Mejía, E. P., Sierra, J. A., Corrales-Agudelo, V., Carmona, J. A., Abad, J. M., \& Escobar, J. S. (2019). Higher Fecal Short-Chain Fatty Acid Levels Are Associated with Gut Microbiome Dysbiosis, Obesity, Hypertension and Cardiometabolic Disease Risk Factors. Nutrients, 11, 51. https://doi.org/ 10.3390/nu11010051

Dehhaghi M, Kazemi H, Panahi S and Guillemin GJ (2019) Microorganisms, tryptophan metabolism, and kynurenine pathway: A complex interconnected loop influencing human health status. International Journal of Tryptophan Research 12, 1-10. https://doi.org/10.1177/1178646919852996

Delzenne NM (2003) Oligosaccharides: State of the art. Proceedings of the Nutrition Society 62, 177-182. https://doi.org/ 10.1079/PNS2002225 
Desbonnet L, Clarke G, Shanahan F, Dinan TG and Cryan JF (2014) Microbiota is essential for social development in the mouse. Molecular Psychiatry 19, 146-148. https://doi.org/10.1038/mp.2013.65

Di Caro V, Cummings JL, Alcamo AM, Piganelli JD, Clark RSB, Morowitz MJ and Aneja RK (2019) Dietary cellulose supplementation modulates the immune response in a murine endotoxemia model. Shock 51(4), 526-534. https://doi.org/ 10.1097/SHK.0000000000001180

Dowlati Y, Herrmann N, Swardfager W, Liu H, Sham L, Reim EK and Lanctôt KL (2010) A meta-analysis of cytokines in major depression. Journal of Biological Psychiatry 67, 446-457. https://doi.org/10.1016/j.biopsych.2009.09.033

European Commision (2011) Commission Regulation (EU) No 1160/2011 of 14 November 2011 on the Authorisation and Refusal of Authorisation of Certain Health Claims Made on Foods and Referring to the Reduction of Disease Risk. 20 September 2021 Available at https://eur-lex.europa.eu/LexUriServ/LexUriServ.do?uri=OJ:L:2011:296:0026:0028:EN:PDF.

European Commision (2012) Commission Regulation (EU) NO 432/2012 of 16 May 2012 Establishing a List of Permitted Health Claims Made on Foods, Other Than Those Referring to the Reduction of Disease Risk and to Children's Development and Health.

Farhangi MA, Zare Javid A, Sarmadi B, Karimi P and Dehghan P (2018) A randomized controlled trial on the efficacy of resistant dextrin, as functional food, in women with type 2 diabetes: Targeting the hypothalamicepituitaryeadrenal axis and immune system. Clinical Nutrition 37, 1216-1223. https://doi.org/10.1016/j.clnu.2017.06.005

Feng Y, Wang Y, Wang P, Huang Y and Wang F (2018) Short-chain fatty acids manifest stimulative and protective effects on intestinal barrier function through the inhibition of NLRP3 inflammasome and autophagy. Cellular Physiology and Biochemistry 49, 190-205. https://doi.org/10.1159/000492853

Fernandes R, do VA, Mocellin MC, Kuntz MGF and Trindade EBSM (2017) Effects of inulin-type fructans, galactooligosaccharides and related synbiotics on inflammatory markers in adult patients with overweight or obesity: A systematic review. Clinical Nutrition 36(5), 1197-1206. https://doi.org/10.1016/j.clnu.2016.10.003

Food and Drug Administration (2019) Food and Drug Administration: Food for Human Consumption. 05 November 2020 Available at https://www.accessdata.fda.gov/scripts/cdrh/cfdocs/cfcfr/cfrsearch.cfm?fr=101.81.

Food and Drug Administration (2020) Food Labeling and Nutrition: Questions and Answers on Dietary Fiber. Available at https://www.fda.gov/food/food-labeling-nutrition/questions-and-answers-dietary-fiber\#synthetic_fibers.

Forte G, De Pascalis V, Favieri F and Casagrande M (2020) Effects of blood pressure on cognitive performance: A systematic review. Journal of Clinical Medicine 9(1), 34. https://doi.org/10.3390/jcm9010034

Fries E, Dettenborn L and Kirschbaum C (2009) The cortisol awakening response (CAR): Facts and future directions. International Journal of Psychophysiology 72, 67-73. https://doi.org/10.1016/j.ijpsycho.2008.03.014

Fuller S, Beck E, Salman H and Tapsell L (2016) New horizons for the study of dietary fiber and health: A review. Plant Foods for Human Nutrition 71(1), 1-12. https://doi.org/10.1007/s11130-016-0529-6

Gibson GR, Hutkins R, Ellen Sanders M, Prescott SL, Reimer RA, Salminen SJ, Scott K, Stanton C, Swanson KS, Cani PD, Verbeke K and Reid G (2017) Expert consensus document: The International Scientific Association for Probiotics and Prebiotics (ISAPP) consensus statement on the definition and scope of prebiotics. Nature Reviews Gastroenterology \& Hepatology 14, 491-502. https://doi.org/10.1038/nrgastro.2017.75

Gill SK, Rossi M, Bajka B and Whelan K (2020) Dietary fibre in gastrointestinal health and disease. Nature Reviews Gastroenterology \& Hepatology 18(2), 101-116. https://doi.org/10.1038/s41575-020-00375-4

Gomez-Pinilla F (2008) Brain foods: The effects of nutrients on brain function. Nature Reviews Neuroscience 9, 568-578. https://doi.org/10.1038/nrn2421Talbott.

Grigoleit J-S, Kullmann JS, Wolf OT, Hammes F and Wegner A (2011) Dose-dependent effects of endotoxin on neurobehavioral functions in humans. PLoS One 6(12), 28330. https://doi.org/10.1371/journal.pone.0028330

Grimaldi R, Gibson GR, Vulevic J, Giallourou N, Castro-Mejía JL, Hansen LH, Leigh Gibson E, Nielsen DS and Costabile A (2018) A prebiotic intervention study in children with autism spectrum disorders (ASDs). Microbiome 6(1), 1-13. https:// doi.org/10.1186/s40168-018-0523-3

Gronier B, Savignac HM, Di Miceli M, Idriss SM, Tzortzis G, Anthony D and Burnet PWJ (2018) Increased cortical neuronal responses to NMDA and improved attentional set-shifting performance in rats following prebiotic (B-GOS $\left.{ }^{\circledR}\right)$ ingestion. European Neuropsychopharmacology 28(1), 211-224. https://doi.org/10.1016/j.euroneuro.2017.11.001

Gupta A, Perdomo S, Billinger S, Beddhu S, Burns J and Gronseth G (2020) Treatment of hypertension reduces cognitive decline in older adults: A systematic review and meta-analysis. BMJ Open 10, 38971. https://doi.org/10.1136/bmjopen-2020038971

Haghighat N, Rajabi S and Mohammadshahi M (2019) Effect of synbiotic and probiotic supplementation on serum brainderived neurotrophic factor level, depression and anxiety symptoms in hemodialysis patients: A randomized, doubleblinded, clinical trial. Nutritional Neuroscience 24(6), 490-499. https://doi.org/10.1080/1028415X.2019.1646975

Hannestad J, Dellagioia N and Bloch M (2011) The effect of antidepressant medication treatment on serum levels of inflammatory cytokines: A meta-analysis. Neuropsychopharmacology 36, 2452-2459. https://doi.org/10.1038/npp.2011.132

Harris AP, Lennen RJ, Brydges NM, Jansen MA, Pernet CR, Whalley HC, Marshall I, Baker S, Basso AM, Day M, Holmes MC and Hall J (2016) The role of brain-derived neurotrophic factor in learned fear processing: An awake rat fMRI study. Genes, Brain and Behavior 15, 221-230. https://doi.org/10.1111/gbb.12277 
Harris HC, Edwards CA and Morrison DJ (2017) Impact of glycosidic bond configuration on short chain fatty acid production from model fermentable carbohydrates by the human gut microbiota. Nutrients 9(1), 26. https://doi.org/10.3390/nu9010026

Hiles SA, Baker AL, De Malmanche T and Attia J (2012) Interleukin-6, C-reactive protein and interleukin-10 after antidepressant treatment in people with depression: A meta-analysis. Psychological Medicine 42(10), 2015-2026. https:// doi.org/10.1017/S0033291712000128

Intlekofer KA, Berchtold NC, Malvaez M, Carlos AJ, Mcquown SC, Cunningham MJ, Wood MA and Cotman CW (2013) Exercise and sodium butyrate transform a subthreshold learning event into long-term memory via a brain-derived neurotrophic factor-dependent mechanism. Neuropsychopharmacology 38, 2027-2034. https://doi.org/10.1038/ npp.2013.104

Jacka FN, O’Neil A, Opie R, Itsiopoulos C, Cotton S, Mohebbi M, Castle D, Dash S, Mihalopoulos C, Chatterton ML, Brazionis L, Dean OM, Hodge AM and Berk (2017) A randomised controlled trial of dietary improvement for adults with major depression (the "SMILES" trial). BMC Medicine 15(1), 1-14. https://doi.org/10.1186/s12916-017-0791-y

Jenkins DJA, Kendall CWC, Axelsen M, Augustin LSA and Vuksan V (2000) Viscous and nonviscous fibres, nonabsorbable and low glycaemic index carbohydrates, blood lipids and coronary heart disease. Current Opinion in Lipidology 11(1), 49-56. https://doi.org/10.1097/00041433-200002000-00008

Jiang H, Ling Z, Zhang Y, Mao H, Ma Z, Yin Y, Wang W, Tang W, Tan Z, Shi J, Li L and Ruan B (2015) Altered fecal microbiota composition in patients with major depressive disorder. Brain, Behaviour, and Immunity 48, 186-194. https:// doi.org/10.1016/j.bbi.2015.03.016

Joint FAO/WHO Food Standards Programme Secretariat of the CODEX Alimentarius Commission (2010) CODEX Alimentarius (CODEX) Guidelines on Nutrition Labeling CAC/GL 2-1985 as Last Amended 2010. Rome: FAO.

Kao ACC, Safarikova J, Marquardt T, Mullins B and Lennox B (2019) Pro-cognitive effect of a prebiotic in psychosis: A double blind placebo controlled cross-over study. Schizophrenia Research 208, 460-461.

Kao ACC, Spitzer S, Anthony DC, Lennox B and Burnet PWJ (2018) Prebiotic attenuation of olanzapine-induced weight gain in rats: Analysis of central and peripheral biomarkers and gut microbiota. Translational Psychiatry 8(1), 66. https://doi.org/ 10.1038/s41398-018-0116-8

Kato T, Monji A, Hashioka S and Kanba S (2007) Risperidone significantly inhibits interferon- $\gamma$-induced microglial activation in vitro. Schizophrenia Research 92, 108-115. https://doi.org/10.1016/j.schres.2007.01.019

Katzbauer B (1998) Properties and applications of xanthan gum. Polymer Degradation and Solubility 59, 81-84.

Kazemi A, Noorbala AA, Azam K, Eskandari MH and Djafarian K (2019) Effect of probiotic and prebiotic vs placebo on psychological outcomes in patients with major depressive disorder: A randomized clinical trial. Clinical Nutrition 38(2), 522-528. https://doi.org/10.1016/j.clnu.2018.04.010

Kendig MD, Lin CS, Beilharz JE, Rooney KB and Boakes RA (2014) Maltodextrin can produce similar metabolic and cognitive effects to those of sucrose in the rat. Appetite 77, 1-12. https://doi.org/10.1016/j.appet.2014.02.011

Kim C-S, Byeon S and Shin D-M (2020) Sources of dietary fiber are differently associated with prevalence of depression. Nutrients 12, 2813. https://doi.org/10.3390/nu12092813

Kim EJ, Hong J and Hwang J-W (2019) The association between depressive mood and cholesterol levels in korean adolescents. Korean Neuropsychiatric Association 16(10), 737-744. https://doi.org/10.30773/pi.2019.03.24

Kim S, Goel R, Kumar A, Qi Y, Lobaton G, Hosaka K, Mohammed M, Handberg EM, Richards EM, Pepine CJ and Raizada MK (2018) Imbalance of gut microbiome and intestinal epithelial barrier dysfunction in patients with high blood pressure. Clinical Science 132, 701-718. https://doi.org/10.1042/CS20180087

Kim SJ, Han K-T, Jang S-Y and Park E-C (2018) The association between low level of high-density lipoprotein cholesterol and mood disorder using time-dependent analysis. Journal of Affective Disorders 225, 317-325. https://doi.org/10.1016/ j.jad.2017.08.016

Kim Y-K, Jung H-G, Myint A-M, Kim H and Park S-H (2007) Imbalance between pro-inflammatory and anti-inflammatory cytokines in bipolar disorder. Journal of Affective Disorders 104, 91-95. https://doi.org/10.1016/j.jad.2007.02.018

Krogh J, Benros ME, Jørgensen MB, Vesterager L, Elfving B and Nordentoft M (2014) The association between depressive symptoms, cognitive function, and inflammation in major depression. Brain, Behavior, and Immunity 35, 70-76. https:// doi.org/10.1016/j.bbi.2013.08.014

La Rosa SL, Kachrimanidou V, Buffetto F, Pope PB, Pudlo NA, Martens EC, Rastall RA, Gibson GR and Westereng B (2019) Wood-derived dietary fibers promote beneficial human gut microbiota. Applied and Environmental Science 4(1), e00554-18. https://doi.org/10.1128/mSphere.00554-18

Lattimer JM and Haub MD (2010) Effects of dietary fiber and its components on metabolic health. Nutrients 2(12), 1266-1289. https://doi.org/10.3390/nu2121266

Lawton CL, Walton J, Hoyland A, Howarth E, Allan P, Chesters D and Dye L (2013) Short term (14 days) consumption of insoluble wheat bran fibre-containing breakfast cereals improves subjective digestive feelings, general wellbeing and bowel function in a dose dependent manner. Nutrients 5(4), 1436-1455. https://doi.org/10.3390/nu5041436

Lecerf J-M, Dépeint F, Clerc E, Dugenet Y, Niamba CN, Rhazi L, Cayzeele A, Abdelnour G, Jaruga A, Younes H, Jacobs H, Lambrey G, Abdelnour AM and Pouillart PR (2012) Xylo-oligosaccharide (XOS) in combination with inulin modulates 
both the intestinal environment and immune status in healthy subjects, while XOS alone only shows prebiotic properties. British Journal of Nutrition 108, 1847-1858. https://doi.org/10.1017/S0007114511007252

Lechleitner M, Hoppichler F, Konwalinka G, Patsch JR and Braunsteiner H (1992) Depressive symptoms in hypercholesterolaemic patients treated with pravastatin. The Lancet 340(8824), 910.

Lehto SM, Niskanen L, Tolmunen T, Hintikka J, Viinamäki H, Heiskanen T, Honkalampi K, Kokkonen M and KoivumaaHonkanen H (2010) Low serum HDL-cholesterol levels are associated with long symptom duration in patients with major depressive disorder. Psychiatry and Clinical Neurosciences 64(3), 279-283. https://doi.org/10.1111/j.14401819.2010.02079.x

Lewis K, Lutgendorff F, Phan V, Söderholm JD, Sherman PM and McKay D (2010) Enhanced translocation of bacteria across metabolically stressed epithelia is reduced by butyrate. Inflammatory Bowel Diseases 16(7), 1138-1148.

Looijer-Van Langen MAC and Dieleman LA (2009) Prebiotics in chronic intestinal inflammation. Inflammatory Bowel Diseases 15(3), 454-462. https://doi.org/10.1002/ibd.20737

Maggo S, Clark D and Ashton JC (2012) The effect of statins on performance in the Morris water maze in Guinea pig. European Journal of Pharmacology 674, 287-293. https://doi.org/10.1016/j.ejphar.2011.11.006

Marcques FZ, Nelson E, Chu P-Y, Horlock D, Fiedler A, Ziemann M, Tan JK, Kuruppu S, Rajapakse NW, El-Osta A, Mackay CR and Kaye DM (2017) High-fiber diet and acetate supplementation change the gut microbiota and prevent the development of hypertension and heart failure in hypertensive mice. Ciculation 135, 964-977. https://doi.org/10.1161/ CIRCULATIONAHA.116.024545

Matt SM, Allen JM, Lawson MA, Mailing LJ, Woods JA and Johnson RW (2018) Butyrate and dietary soluble fiber improve neuroinflammation associated with aging in mice. Frontiers in Immunology 9, 14. https://doi.org/10.3389/ fimmu.2018.01832

McLoughlin RF, Berthon BS, Jensen ME, Baines KJ and Wood LG (2017) Short-chain fatty acids, prebiotics, synbiotics, and systemic inflammation: A systematic review and meta-analysis. The American Journal of Clinical Nutrition 106, 930-945. https://doi.org/10.3945/ajen

McRorie JW and McKeown NM (2017) Understanding the physics of functional fibers in the gastrointestinal tract: An evidence-based approach to resolving enduring misconceptions about insoluble and soluble fiber. Journal of the Academy of Nutrition and Dietetics 117(2), 251-264. https://doi.org/10.1016/j.jand.2016.09.021

Messaoudi M, Lalonde R, Violle N, Javelot H, Desor D, Nejdi A, Bisson J-F, Rougeot C, Pichelin M, Cazaubiel M and Cazaubiel J-M (2011) Assessment of psychotropic-like properties of a probiotic formulation (Lactobacillus helveticus R0052 and Bifidobacterium longum R0175) in rats and human subjects. British Journal of Nutrition 105, 755-764. https://doi.org/ 10.1017/S0007114510004319

Monk JM, Lepp D, Wu W, Pauls KP, Robinson LE and Power KA (2017) Navy and black bean supplementation primes the colonic mucosal microenvironment to improve gut health. Journal of Nutritional Biochemistry 49, 89-100. https://doi.org/ 10.1016/j.jnutbio.2017.08.002

Morales K, Wittink M, Datto C, Difilippo S, Cary M, Tenhave T and Katz IR (2006) Simvastatin causes changes in affective processes in elderly volunteers. Journal of the American Geriatrics Society 54, 70-76. https://doi.org/10.1111/j.15325415.2005.00542.x

Mudgil D and Barak S (2013) Composition, properties and health benefits of indigestible carbohydrate polymers as dietary fiber: A review. International Journal of Biological Macromolecules 61, 1-6. https://doi.org/10.1016/j.ijbiomac.2013.06.044

Mudgil D, Barak S and Khatkar BS (2014) Optimization of enzymatic hydrolysis of guar gum using response surface methodology. Journal of Food Science and Technology 51(8), 1600-1605. https://doi.org/10.1007/s13197-012-0678-z

Muela HCS, Costa-Hong VA, Yassuda MS, Moraes NC, Memória CM, Machado MF, Macedo TA, Shu EBS, Massaro AR, Nitrini R, Mansur AJ and Bortolotto LA (2017) Hypertension severity is associated with impaired cognitive performance. Journal of the American Heart Association 6(1), e004579. https://doi.org/10.1161/JAHA.116.004579

Murphy EA, Davis JM and Carmichael MD (2010) Immune modulating effects of $\beta$-glucan. Current Opinion in Clinical Nutrition and Metabolic Care 13(6), 656-661. https://doi.org/10.1097/MCO.0b013e32833flafb

Muth AK and Park SQ (2021) The impact of dietary macronutrient intake on cognitive function and the brain. Clinical Nutrition 40(6), 3999-4010. https://doi.org/10.1016/j.clnu.2021.04.043

Ohlsson L, Gustafsson A, Lavant E, Suneson K, Brundin L, Westrin, Ljunggren L and Lindqvist D (2019) Leaky gut biomarkers in depression and suicidal behavior. Acta Psychiatrica Scandinavica 139(2), 185-193. https://doi.org/10.1111/ acps. 12978

Onumpai C, Kolida S, Bonnin E and Rastall RA (2011) Microbial utilization and selectivity of pectin fractions with various structures. Applied and Environmental Microbiology 77(16), 5747-5754. https://doi.org/10.1128/AEM.00179-11

Pasman WJ, Blokdijk VM, Bertina FM, Hopman W and Hendriks H (2003) Effect of two breakfasts, different in carbohydrate composition, on hunger and satiety and mood in healthy men. International Journal of Obesity 27, 663-668. https://doi.org/ 10.1038/sj.ijo.0802284

Pedersen C, Gallgher E, Horton F, Ellis RJ, Ijaz UZ, Wu H, Jaiyeola E, Diribe O, Duparc T, Cani PD, Gibson GR, Hinton P, Wright J, La Ragione R and Robertson MD (2016) Host-microbiome interactionsin human type 2 diabetes following 
prebiotic fibre (galactooligosaccharide) intake. British Journal of Nutrition 116(11), 1869-1877. https://doi.org/10.1017/ S0007114516004086

Prykhodko O, Sandberg J, Burleigh S, Björck I, Nilsson A and Fåk Hållenius F (2018) Impact of Rye kernel-based evening meal on microbiota composition of young healthy lean volunteers with an emphasis on their hormonal and appetite regulations, and blood levels of brain-derived neurotrophic factor. Frontiers in Nutrition 5, 45. https://doi.org/10.3389/ fnut.2018.00045

Qing Q, Li H, Kumar R and Wyman CE (2013) Xylooligosaccharides production, quantification, and characterization in context of lignocellulosic biomass pretreatment. In Aqueous Pretreatment of Plant Biomass for Biological and Chemical Conversion to Fuels and Chemicals, 1st edn. Hoboken, NJ: Wiley, pp. 391-415. https://doi.org/10.1002/9780470975831.ch19

Rabbani GH, Teka T, Zaman B, Majid N, Khatun M and Fuchs GJ (2001) Clinical studies in persistent diarrhea: Dietary management with green Banana or pectin in Bangladeshi children. Gastroenterology 121(3), 554-560. https://doi.org/ 10.1053/gast.2001.27178

Ramnani P, Costabile A, Bustillo AGR and Gibson GR (2015) A randomised, double-blind, cross-over study investigating the prebiotic effect of agave fructans in healthy human subjects. Journal of Nutritional Science 4, e10. https://doi.org/10.1017/ jns.2014.68

Romo-Araiza A, Gutiérrez-Salmeán G, Galván EJ, Hernández-Frausto M, Herrera-López G, Romo-Parra H, GarcíaContreras V, María Fernández-Presas A, Jasso-Chávez R, Borlongan CV, Ibarra A, Kumar A, Smulders TV and Yegla B (2018) Probiotics and prebiotics as a therapeutic strategy to improve memory in a model of middle-aged rats. Frontiers in Aging Neuroscience 10, 416. https://doi.org/10.3389/fnagi.2018.00416

Russo F, Linsalata M, Clemente C, Chiloiro M, Orlando A, Marconi E, Chimienti G and Riezzo G (2012) Inulin-enriched pasta improves intestinal permeability and modifies the circulating levels of zonulin and glucagon-like peptide 2 in healthy young volunteers. Nutrition Research 32(12), 940-946. https://doi.org/10.1016/j.nutres.2012.09.010

Sajilata MG, Singhal RS and Kulkarni PR (2006) Resistant starch - A review. Comprehensive Reviews in Food Science and Food Safety 5, 1-17.

Sandberg JC, Björck IME and Nilsson AC (2018) Impact of rye-based evening meals on cognitive functions, mood and cardiometabolic risk factors: A randomized controlled study in healthy middle-aged subjects. Nutrition Journal $17,102$. https://doi.org/10.1186/s12937-018-0412-4

Schmidt K, Cowen PJ, Harmer CJ, Tzortzis G, Errington S and Burnet PWJ (2015) Prebiotic intake reduces the waking cortisol response and alters emotional bias in healthy volunteers. Psychopharmacology 232, 1793-1801. https://doi.org/ $10.1007 /$ s00213-014-3810-0

Schreurs BG (2010) The effects of cholesterol on learning and memory. Neuroscience and Biobehavioral Reviews 34, 1366-1379. https://doi.org/10.1016/j.neubiorev.2010.04.010

Shapiro D, Jamner LD, Goldstein IB and Delfino RJ (2001) Striking a chord: Moods, blood pressure, and heart rate in everyday life. Psychophysiology 38(2), 197-204. https://doi.org/10.1111/1469-8986.3820197

Shaw RJ, Mackay D, Pell JP, Padmanabhan S, Bailey DS and Smith DJ (2020) The relationship between antihypertensive medications and mood disorders: Analysis of linked healthcare data for 1.8 million patients. Psychological Medicine 51, 1183-1191. https://doi.org/10.1017/S0033291719004094

Sherry CL, Kim SS, Dilger RN, Bauer LL, Moon ML, Tapping RI, Fahey GC, Tappenden KA and Freund GG (2010) Sickness behavior induced by endotoxin can be mitigated by the dietary soluble fiber, pectin, through up-regulation of IL-4 and Th2 polarization. Brain Behavior and Immunity 24, 631-640. https://doi.org/10.1016/j.bbi.2010.01.015

Silk DBA, Davis A, Vulevic J, Tzortzis G and Gibson GR (2009) Clinical trial: The effects of a trans-galactooligosaccharide prebiotic on faecal microbiota and symptoms in irritable bowel syndrome. Alimentary Pharmacology \& Therapeutics 29(5), 508-518. https://doi.org/10.1111/j.1365-2036.2008.03911.x

Singh N, Gurav A, Sivaprakasam S, Brady E, Padia R, Shi H, Thangaraju M, Prasad PD, Manicassamy S, Munn DH, Lee JR, Offermanns S and Ganapathy V (2014) Activation of Gpr109a, receptor for niacin and the commensal metabolite butyrate, suppresses colonic inflammation and carcinogenesis. Immunity 40(1), 128-139. https://doi.org/10.1016/j. immuni.2013.12.007

Smith AP (2005) The concept of well-being: Relevance to nutrition research. British Journal of Nutrition 93(1), S1-S5.

Smith AP, Sutherland D and Hewlett P (2015) An investigation of the acute effects of oligofructose-enriched inulin on subjective wellbeing, mood and cognitive performance. Nutrients 7(11), 8887-8896. https://doi.org/10.3390/nu7115441

Smith PM, Howitt MR, Panikov N, Michaud M, Gallini CA, Bohlooly-Y M, Glickman JN and Garrett WS (2013) The microbial metabolites, short-chain fatty acids, regulate colonig Treg cell homeostasis. Science 341, 569-573. https://doi.org/ 10.1126/science.1237947

Sobotka L, Brátova M, Šlemrová M, Maňák J, Vižd’a J and Zadák Z (1997) Inulin as the soluble fiber in liquid enteral nutrition. Nutrition 13(1), 21-25. https://doi.org/10.1016/S0899-9007(97)90874-1

Song J, Li Q, Everaert N, Liu R, Zheng M, Zhao G and Wen J (2020) Effects of inulin supplementation on intestinal barrier function and immunity in specific pathogen-free chickens with salmonella infection. Journal of Animal Science 2020(1), 1-10. https://doi.org/10.1093/jas/skz396 
Stevens BR, Goel R, Seungbum K, Richards EM, Holbert RC, Pepine CJ and Raizada MK (2018) Increased human intestinal barrier permeability plasma biomarkers zonulin and FABP2 correlated with plasma LPS and altered gut microbiome in anxiety or depression. Gut 67(8), 1555-1557. https://doi.org/10.1136/gutjnl-2017-314759

Stilling RM, van de Wouw M, Clarke G, Stanton C, Dinan TG and Cryan JF (2016) The neuropharmacology of butyrate: The bread and butter of the microbiota-gut-brain axis? Neurochemistry International 99, 110-132. https://doi.org/10.1016/ j.neuint.2016.06.011

Strike PC, Wardle J and Steptoe A (2004) Mild acute inflammatory stimulation induces transient negative mood. Journal of Psychosomatic Research 57, 189-194. https://doi.org/10.1016/S0022-3999(03)00569-5

Suzuki T, Yoshida S and Hara H (2008) Physiological concentrations of short-chain fatty acids immediately suppress colonic epithelial permeability. British Journal of Nutrition 100, 297-305. https://doi.org/10.1017/S0007114508888733

Swann OG, Kilpatrick M, Breslin M and Oddy WH (2020) Dietary fiber and its associations with depression and inflammation. Nutrition Reviews 78(5), 394-411. https://doi.org/10.1093/nutrit/nuz072

Talbott S and Talbott J (2009) Effect of BETA 1, 3/1, 6 GLUCAN on upper respiratory tract infection symptoms and mood state in marathon athletes. Journal of Sports Science and Medicine 8, 509-515. 04 August 2020. Available at http://www.jssm.org.

Tedders SH, Fokong KD, Mckenzie LE, Wesley C, Yu L, and Zhang J (2011) Low cholesterol is associated with depression among US household population. Journal of Affective Disorders 135, 115-121. https://doi.org/10.1016/j.jad.2011.06.045

Van De Wouw M, Boehme M, Lyte JM, Wiley N, Strain C, O'sullivan O, Clarke G, Stanton C, Dinan TG, Cryan JF, Barrett K, Grundy D and Cryan JF (2018) Short-chain fatty acids: Microbial metabolites that alleviate stress-induced brain-gut axis alterations. The Journal of Physiology C 596, 4923-4944. https://doi.org/10.1113/JP276431

Verhaar BJ, Collard D, Prodan A, Levels JH, Zwinderman AH, Bäckhed F, Vogt L, Peters MJ, Muller M, Nieuwdorp M and van den Born B-JH (2020) Associations between gut microbiota, faecal short-chain fatty acids, and blood pressure across ethnic groups: The HELIUS study. European Heart Journal 41, 4259-4267. https://doi.org/10.1093/eurheartj/ehaa760

Vetere G, Ripaldi L, Ais E, Korob G, Kes M and Villamil A (2007) Prevalence of anxiety disorders in patients with essential hypertension. Vertex 18(71), 20-25.

Vinolo MAR, Rodrigues HG, Nachbar RT and Curi R (2011) Regulation of inflammation by short chain fatty acids. Nutrients 3(10), 858-876. https://doi.org/10.3390/nu3100858

Vulevic J, Drakoularakou A, Yaqoob P, Tzortzis G and Gibson GR (2008) Modulation of the fecal microflora profile and immune function by a novel trans-galactooligosaccharide mixture (B-GOS) in healthy elderly volunteers 1-3. The American Journal of Clinical Nutrition 88, 1438-1484. https://doi.org/10.3945/ajcn.2008.26242

Waldecker M, Kautenburger T, Daumann H, Busch C and Schrenk D (2008) Inhibition of histone-deacetylase activity by short-chain fatty acids and some polyphenol metabolites formed in the colon. Journal of Nutritional Biochemistry 19, 587-593. https://doi.org/10.1016/j.jnutbio.2007.08.002

Wang H-X and Gao W-J (2009) Cell type-specific development of NMDA receptors in the interneurons of rat prefrontal cortex. Neuropsychopharmacology 34, 2028-2040. https://doi.org/10.1038/npp.2009.20

Wang L, Zhu Q, Lu A, Liu X, Zhang L, Xu C, Liu X, Li H and Yang T (2017) Sodium butyrate suppresses angiotensin IIinduced hypertension by inhibition of renal (pro)renin receptor and intrarenal renin-angiotensin system. Journal of Hypertension 35(9), 1899-1908. https://doi.org/10.1097/HJH.0000000000001378

Wright CE, Strike PC, Brydon L and Steptoe A (2005) Acute infammation and negative mood: Mediation by cytokine activation. Brain, Behavior, and Immunity 19, 345-350. https://doi.org/10.1016/j.bbi.2004.10.003

Yang CC, Jick SS and Jick H (2003) Lipid-lowering drugs and the risk of depression and suicidal behavior. Archives of Internal Medicine 163(16), 1926-1932. https://doi.org/10.1001/archinte.163.16.1926

Yang T, Magee KL, Colon-Perez LM, Larkin R, Liao Y-S, Balazic E, Cowart JR, Arocha R, Redler T, Febo M, Vickroy T, Martyniuk CJ, Reznikov LR and Zubcevic J (2019) Impaired butyrate absorption in the proximal colon, low serum butyrate and diminished central effects of butyrate on blood pressure in spontaneously hypertensive rats. Acta Physiologica 226(2), e13256. https://doi.org/10.1111/apha.13256

Yang T, Santisteban MM, Rodriguez V, Li E, Ahmari N, Carvajal JM, Zadeh M, Gong M, Qi Y, Zubcevic J, Sahay B, Pepine CJ, Raizada MK and Mohamadzadeh M (2015) Gut dysbiosis is linked to hypertension. Hypertension 65(6), 1331-1340. https://doi.org/10.1161/HYPERTENSIONAHA.115.05315

Zheng P, Zeng B, Zhou C, Liu M, Fang Z, Xu X, Zeng L, Chen J, Fan S, Du X, Zhang X, Yang D, Yang Y, Meng H, Li W, Melgiri ND, Licinio J, Wei H and Xie P (2016) Gut microbiome remodeling induces depressive-like behaviors through a pathway mediated by the host's metabolism. Molecular Psychiatry 21, 786-796. https://doi.org/10.1038/mp.2016.44

Cite this article: La Torre D., Verbeke K., and Dalile B. 2021. Dietary fibre and the gut-brain axis: microbiota-dependent and independent mechanisms of action. Gut Microbiome, 2, e3, 1-26. https://doi.org/10.1017/gmb.2021.3

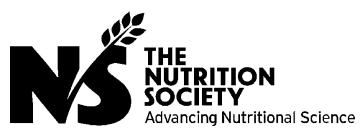

